\title{
Topoğrafik Yüzey Değişimlerinin Görüntü İşleme Teknikleriyle Belirlenmesi Üzerine Bir Araştırma
}

\author{
Mustafa Zeybek ${ }^{1, \oplus}$, İsmail Şanlıoğlu²® \\ ${ }^{1}$ Artvin Çoruh Üniversitesi, Mühendislik Fakültesi, Harita Mühendisliği Bölümü, 08100, Artvin \\ ${ }^{2}$ Konya Teknik Üniversitesi Mühendislik ve Doğa Bilimleri Fakültesi, Harita Mühendisliği Bölümü, 42250, Konya.
}

\section{Özet}

Bu çalışma, topoğrafik yüzeylerde meydana gelen hareketlerin izlenmesinde Insansız Hava Aracı (IHHA) kullanımını sunmaktadır. Çalışmada farklı zamanlarda elde edilen görüntülerde komşuluk ve korelasyon ilişkileriyle yüzey hareketlerinin ortaya çıarılması amaçlanmaktadır. Son yllların en yeni ve etkili ölçme teknolojisi hiç şüphesiz IHA'dır. IHA görüntüleri, santimetre hassasiyette çözüm üretebilen Küresel Konumlandırma Uydu Sistemleri (GNSS) ile birlikte kullanılarak yüzey hareketlerinin tespit edilmesi için değerlendirilmiştir. Bu çalışma kapsamında belirli zaman aralığında elde edilen verilerdeki özel detaylar otomatik çıkarılarak görüntülerdeki topoğrafik yüzeyin farklı sebeplerle oluşan değişimleri gözlemlenmiștir. Aynı koordinat sistemine sahip farklı zamanlarda elde edilen ortomozaikler arasındaki benzerlik ve farklllıklardan yararlanarak görüntüler üzerindeki topoğrafik yüzey özellikleri incelenebilmektedir. Çalışma bölgesi olarak heyelan vakalarının yoğun olarak görüldüğü Taşkent (Konya) ilçesi seçilmişstir. IHA görüntülerinden elde edilen ortomozaik ve sayısal arazi modeli verileri, yüzey hareketlerinin yatay ve düşey yönde tespit edilmesinde kullanılmıştır. Planimetrik olarak $0.005 \mathrm{~m} /$ gün hızda yer değiştirmeler, düşeyde ise ortalama $0.004 \mathrm{~m} / g u ̈ n ~ h a r e k e t l e r ~ t e s p i t$ edilmiştir.

\section{Anahtar Sözcükler}

Heyelan İzleme, Ortomozaik, İnsansız Hava Aracı, Görüntü Eşleme, Sayısal Arazi Modeli

\section{A Study on Determination of Topographical Surface Changes by Image Processing Techniques}

\begin{abstract}
This study presents the use of Unmanned Aerial Vehicle (UAV) for monitoring movements on topographic surfaces. In the study, it is aimed to reveal surface movements with neighbouring and correlation relations in the images obtained at different times. The latest and most effective measuring technology of recent years is undoubtedly UAV. UAV images were used together with Global Navigation Satellite System (GNSS), which can produce solutions with centimetre accuracy to evaluate surface movements. Within the scope of this study, the individual details which are extracted automatically on the images obtained at certain time intervals, changes caused by various reasons on the topographic surface, were observed. By using the similarities and differences between orthomosaics obtained at different times with the same coordinate system, topographic surface properties on the images can be examined. Taşkent (Konya) province where landslide cases are seen as intense in the study area was selected. The orthomosaic and digital terrain model data obtained by UAV images were used to determine the horizontal and vertical direction of the surface movements. Planimetric displacements at $0.005 \mathrm{~m} /$ day and $0.004 \mathrm{~m} /$ day movements at vertical were determined.
\end{abstract}

$\underline{\text { Keywords }}$

Landslide Monitoring, Orthomosaic, Unmanned Aerial Vehicle, Image Matching, Digital Terrain Model

\section{Giriş}

Doğal afetler; deprem, heyelan, ani su baskınları, küresel anlamda oluşan iklimsel değişimlerden hızlı etkilenen olgulardır. Doğal afetlerin oluşması geniş çaplı alanları etki altına alarak insan yapılarının deformasyonuna, can ve mal kayıplarına sebep olmaktadır. Sürekli hareket halindeki yerin yapısının bir süreci olarak göze çarpan bu olaylar yıkıcı etkileri sebebiyle ekonomik ve sosyal sonuçları büyük kitleleri etkileyen doğal olaylar bütünüdür.

Yeryüzünde oluşan yüzeysel hareketlerin tespiti ve ölçümü, özellikle, tektonik, deprem, toprak kayması, buzul hareketleri ve çığ gibi birçok jeomorfolojik, jeolojik ve meteorolojik süreçlerin incelenmesi, anlaşılması olumsuz etkileri nedeniyle çok önemlidir. Yüzeysel değişimlerin ölçülmesi ve de haritalanması genel olarak Harita Mühendisliğinin görevleri arasındadır. Yaygın olarak Harita mühendisliğinin konusunu yersel ölçmeler oluşturur. Küçük boyutta veya karmaşık yapıdaki bölgelerde oluşan yeryüzü değişimlerinin izlenmesinde ise karşılaşılan bazı ölçme zorlukları nedeniyle yersel ölçmelerin uygulanmadığ 
Bu gibi durumlarda uzaktan algılama teknikleri öne çıkmaktadır (Akıncı vd. 2010; Kargel vd. 2014; Türk 2018). Bu nedenle yer ve yüzey hareketlerinin doğrudan ölçümü kapsamlı bir jeodezik çalışmaya dönüşür. Anadolu coğrafyamızın neredeyse tamamında farklı tür ve etkideki afetler, onlarca, yüzlerce insanı olumsuz etkilerine maruz bırakmaktadır (Gokceoglu 2002; Aydan vd. 2008; Karsli vd. 2009).

Afetlerin oluşumlarındaki sebepler, topoğrafik etkiler, dünya gravitasyonundaki değişimler, iklimsel değişimler ve insanoğlunun doğaya yaptığı değişimler olarak sıralanmaktadır (Scaioni 2015). Doğanın da bu etkilere verdiği tepkiler maalesef ağır olmaktadır (Haque vd. 2016). Ülkemizde alınan zarar bakımından meydana gelen doğal afetlerden ilki depremlerdir (Çan vd. 2013). Heyelanlar ise, depremlerden sonra gelen, topoğrafya da ağır etkiler bırakan doğal afettir. Özellikle yerleşim yerlerine yakın ve sürekli oluşan heyelanlar ülke ekonomilerine büyük zararlar vermektedir (Scaioni vd. 2014).

Ülkemizde heyelanlar genellikle Karadeniz bölgesinde oluşmaktadır (Akgün ve Bulut 2007; Çan vd. 2013; Haque vd. 2016). Bunun yanında diğer bölgelerde de meydana gelen vakalar mevcuttur. Jeolojik yapılardaki farklılıklar, yağ1ş, yeraltı su seviyesindeki değişimler, toprak su doygunluk oranları, depremler, yol ve inşaat yapıları, ormanların azalması vb. pek çok tetikleyici etkilerle heyelanlar oluşmaktadır (Singh ve Bartlett 2018).

Heyelan karakteristiğinin ve yönünün tespitinde hareketlerin dağılımları önemlidir. Heyelan hareketleri, jeolojik yapı ve jeomorfolojik yapıya bağlı olarak farklı hızlarda etkisini göstermektedir. Ayrıca deformasyon hızlarının tespit edilmesi heyelan karakteristiğinin önemli faktörleri arasındadır (Handwerger vd. 2013).

Heyelanlara karşı bilinçsiz ve yetersiz müdahale, heyelanı durdurmamakta ve etkisini azaltmamaktadır. Bu sebeple tekrarlayan oluşumlarıyla insan yaşamını tehlikeye sokmaktadır. Bu zararlardan kaçınmanın en iyi yolu, potansiyel heyelan duyarlığına sahip alanların tespiti, sürekli veya periyodik olarak izlenmesi ve gerekli önlemleri erken almaktır. Bölgesel olarak yüzey hareketlerinin farklılık göstermesi, kompleks ve karmaşık yapılı heyelanların izlenmesi ve haritalanması, veri yönetimini yapan operatörler için meşakkatlidir. Tek tek noktaların tespit edilmesi yerine, otomatik olarak özellikli noktaların çıkarımı, heyelanın etki alanlarındaki hareketin tespitinde önemli ölçüde kolaylıklar sağlamaktadır. Literatüre bakıldığında heyelan araştırmaları üç kısma ayrılmıştır (Kalkan vd. 2003; van Westen vd. 2008; Akinci vd. 2010). Bunlar:

- Heyelanın tespiti, sınıflandırılması ve heyelan sonrası analizleri,

- Heyelan izleme çalışmaları,

- Heyelan duyarlık ve tehlike değerlendirmeleri

olarak sınıflandırılabilir. Heyelanların tespiti ve tanımlanması, önceki dönemlerde oluşmuş heyelanların belirlenmesi ve tanımlanması çalışmalarını kapsar. Bu araştırmalar sayesinde ilgili bölgelerdeki heyelan sahalarına ait envanter haritaları oluşturulur ve değerlendirilir. Heyelan izlemede yaygın şekilde kullanılan ölçme metotları uzaktan algılama ve jeodezik ölçme yöntemleridir (Zeybek vd. 2015). Bu yöntemlerin diğer geoteknik ölçmelerine göre ucuz maliyetli olması ve iş yükünün daha az olması tercih edilmesinde etkilidir. Heyelan alanlarında ulaşım ve erişim zorlukları, yersel yöntemlerle ölçümlerin uzun sürmesi ve bazı yerlerde ölçümlerin neredeyse imkânsız olması uzaktan algılamayı avantajlı hale getirmektedir. Bu nedenlerden dolayı uzaktan ölçmelerin yapılması, bölgede yüzeye ait verilerin elde edilmesini oldukça kolaylaştırmaktadır.

Yüzey hareketlerini ölçmek için geleneksel ölçme teknikleri; teodolit, total station ve günümüzde yaygın olarak kullanılan Küresel Konumlandırma Uydu Sistemleri (GNSS), tehlikesiz ve erişilebilir alanlarda yüksek doğruluklu konumsal veriyi sağlamaktadır (Gili vd. 2000; Hastaoglu ve Sanli 2011; Hastaoğlu vd. 2014). Ancak, havasal veya uydu temelli uzaktan algılama teknikleri geniş ve/veya erişilemeyen karmaşık alanların izlenmesi için daha uygun teknikler olarak görülmektedir. Günümüzde, yer değiştirme ölçümleri için önemli uzaktan algılama teknikleri, 1ş1k (Lazer) algılama ve mesafe ölçme (LiDAR), Yapay Açıklıklı Radar (SAR/InSAR) ve Fotogrametri teknikleridir (Margottini vd. 2013).

Son yılların en yeni ve etkili ölçme teknolojisi hiç şüphesiz İnsansız Hava Araçları (İHA)'dır (Cömert vd. 2012). Yer bilimleri araştırmaları için İHA ölçme teknolojisi önemli yer edinmiştir. Üretilen yüksek çözünürlüklü gerçek ortofotolar veya birleştirilmiş biçimleriyle, ortomozaikler heyelan bölgelerindeki hareketlerin tespit edilmesine büyük katk1 sağlamaktadır (Niethammer vd. 2012; Lucieer vd. 2014; Turner vd. 2015).

Heyelanların izlenmesi genelde iki farklı grupta incelenir. Bunlar niteliksel koşul incelemeleri, bir diğeri ise nicel, yüzey deformasyonlarının tespit edilmesidir. Bu noktada, yüzey hareketlerinin izlenmesinde daha önce de belirtilen farklı teknikler kullanılmaktadır. Uzaktan algılama ölçme teknikleri kendi içinde gruplandırılabilir. Bunlar;

- Yere yakın uydu sistemleri (Aktif sensörlü ve optik sensörler)

- Yüksek seviye algılama (İnsanlı uçak, helikopter platformlar, aktif ve pasif ölçmeler)

- Yer yakın algilama sistemleri (İHA)

- Yer ölçmeleri (Yersel Fotogrametri, Yersel lazer tarama, Yer Yapay Açıklıklı Sentetik Radar (Ground-based INSAR))

ölçmeleri olarak gruplandırılabilir. Yukarıda sınıflandırması yapılan ölçme sistemleri ile ilgili pek çok çalışma, heyelan izlemede etkili biçimde kullanılmıştır (Lucieer vd. 2014; Türk 2018; Zeybek ve Şanlıoğlu 2018). Literatür çalışmalarına bakıldığında karasal yüzey hareketleri değişimi izlemenin yanı sıra buzul hareketlerinin görüntü tabanlı ölçümü, görüntü çiftleri arasında görüntü dokusuna uyan çeşitli otomatik algoritmalar kullanılarak izleme çalışmaları da yapılmıştır (Scambos vd. 1992; Kaab 2002; Leprince vd. 2007; Messerli ve Grinsted 2015). 
$\mathrm{Bu}$ algoritmalar, optimize edilmiş koşullar altında potansiyel olarak 0.02 piksele eşdeğer doğrulukla, görüntülerden çıkarılan çok sayıda nokta sayesinde farklı görüntülerdeki değişimi ortaya koyabilir seviyededir (Maas vd. 2010). Bununla birlikte, yüzeylerdeki doğal özellikli noktaların ortaya çıkarılmasında sistematik çıkarımlar, hızlı değişen yüzeyler için, tam otomatik eşleştirme sadece belirli alanlarda ve kısa zaman aralıklı periyodik çalışmalar için yapılmaktadır. Bu çalışmanın da temel çıkış noktası, karalarda oluşan yüzey hareketlerinin görüntü işleme temelli yöntemlerle tespitinin yapılabilirliğinin araştırılmasıdır.

Bu makalede, İHA sistemlerinden elde edilen görüntüler üzerinden yüzeysel hareketlerin izlenmesi ve heyelan tespit çalışmaları irdelenmiştir. Ortomozaik görüntülerdeki, özellikli noktaların otomatik çıkarımı ve bu noktaların farklı dönemlerde elde edilen görüntüler üzerindeki noktalarla eşleştirilmesi; heyelan alanındaki yer değiştirmelerin tespiti, bu çalışmada sunulmuştur. Çalışma kapsamında en yaygın görüntü işleme yöntemlerinin ve algoritmaların İHA verilerine uyarlanmasıyla, heyelan bölgelerinin izlenmesine farklı bir bakış açısı getirilmiş, hareketlerin tespitinde otomatik çıkarım yöntemleri incelenmiştir. Heyelan hareketlerinin belirlenmesi iki boyutlu (2B), tek boyutlu (1B) ve üç boyutlu (3B) bileşenlerle yapılmıştır. İHA'dan üretilen yüksek çözünürlüklü ortomozaikler ve sayısal yüzey modeli (SYM) verileri, Konya ili Taşkent ilçesine yakın alanda oluşan heyelan hareketlerinin belirlenmesi ve modellenmesi için kullanılmıştır. Aynı zamanda standart GNSS kullanımına göre avantajları ve dezavantajlarının belirlenmiştir. Bu çalışmada özellikle aşağıda verilen üç farklı probleme çözüm önerisi getirilmiştir.

- İlk olarak, çalışma gerçek bir heyelan sahası uygulamalarını barındırmaktadır, İHA ile heyelan haritalama da olması gereken özellikler ve üretilen SYM kalitesiyle değişimlerin izlenebilirliği ve heyelan tespiti,

- İkincisi, İHA fotogrametrisinden üretilen SYM'lerin ve ortamozaiklerin görüntü işleme teknikleri ile 2B ve 3B ‘lu deformasyonların modellemesi, görüntü eşleme korelasyon parametrelerinin yüzey değişimindeki vektör alanlarına etkisi,

- Üçüncüsü, elde edilen İHA kalitesinin heyelan izleme amaçlı, yersel tekniklerle karşılaştırılması, İHA SYM ve ortomozaik analizleri arasındaki avantajlarının ve dezavantajlarının tartışılmasıdır.

\section{1 Çalışma Alanı}

Çalışma alanı, mekanizması oldukça karmaşık yapıda ve yüksek eğime sahip bir heyelandır (Şekil 1). Bu alanda ölçme çalışmaları zor yapılmaktadır ve bu nedenle heyelanın izlenmesi zordur (Zeybek 2017). Bölgeden geçen karayolu, sulama borularının sürekli zarar görmesi, bahçe ve meyve ağaçlarının kuruması gibi sorunlara neden olmaktadır. Bölge 2011 yılından bu yana problemlerin azaltılması ve zararların en aza indirgenmesi için farklı tekniklerle izlenmektedir (Zeybek ve Şanlıoğlu 2013; Sanlioglu vd. 2016; Zeybek ve Şanlıŏ̆lu 2018).

a)

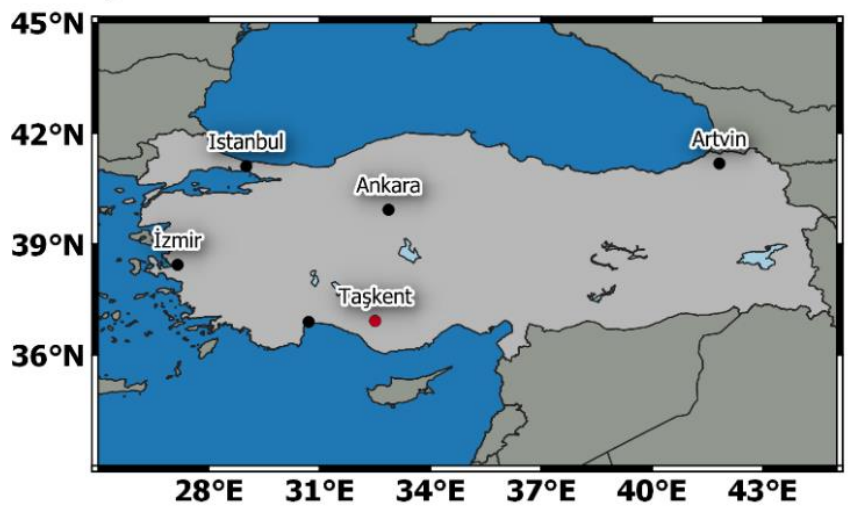

b)

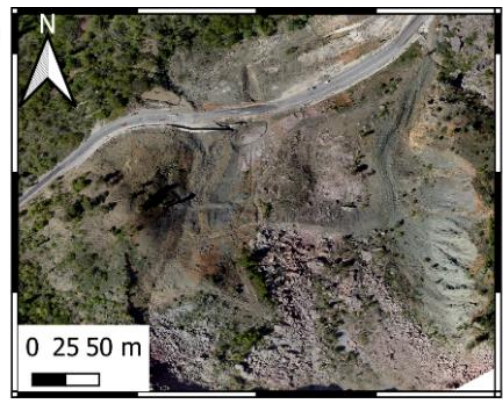

c)

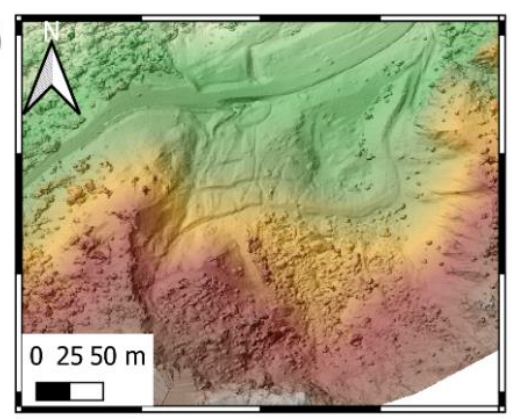

Yükseklik [m]

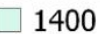

1425

1449

$\square 1473$

$\square 1498$

$\square 1522$

$\square 1546$

1571

1595

1619

Şekil 1: Çalışma bölgesi lokasyon haritası, a) çalışma alanı Türkiye haritasında yeri, b) çalışma bölgesi ortomozaiği, c) çalışma alanı yükseklik haritası

Bölgenin jeomorfolojik özelliklerindeki değişim, periyotlar arasındaki düşey yönlü SYM farklarıyla elde edilmiştir. SYM cebrik yöntemi, özellikle kayaç yapılar ve pürüzlü yüzeylerde meydana gelen düşey yönlü çökme ve kabarma hareketlerinin belirlenmesinde en etkili yöntemdir. Bu yöntemlerin bölge heyelanı için uygulandığı ilk çalışmalar 2011 2013 yıllarında yapılmıştır (Zeybek ve Şanlıŏ̆lu 2013). 


\section{Materyal Metot}

Bu bölümde İHA'dan elde edilen materyallerin analiz edilmesi ve yüzey hareketlerinin çıkarılmasında uygulanan yöntemler hakkında bilgi verilmektedir. Bu çalışmanın temel odak noktası görüntü temelli eşleme algoritmalarıdır. Görüntü eşleme algoritmaları farklı açılardan çekilmiş görüntülerin birleștirilmesinde yaygın olarak kullanılır. Fakat bu çalışmada belirli dönemlerdeki 2B yüzey hareketlerinin ortaya çıkarılması için kullanılmıştır. Önerilen metodoloji sırasıyla sunulan bölümlerde detaylı olarak verilmiştir: (i) İHA veri toplama, (ii) İHA veri ön işleme, (iii) yoğun eşleme, (iv) SYM ve Ortomozaik üretimi, (v) görüntü eşleme, (vi) Yüzey hareketinin hesaplaması.

\subsection{IHA Veri Toplama}

İHA verileri iki grupta sınıflandırılabilir. Bunlar; Jeodezik ölçmelerden gelen yer kontrol nokta (YKN)'ları ve kameradan elde edilen resimlerdir. Yükseklik modelleri ve ortomozaiklerin jeodezik amaçlı konumlandırılmaları için kullanılmışıır. YKN'larının yeterli sayıda olması elde edilecek model kalitesini etkileyeceği için minimum 3 adet olmakla birlikte arazinin topoğrafik koşullarına da bağlı olarak optimum sayıda olmasına özen gösterilmelidir. Fazla sayıda ölçülen yer kontrol noktaları sayesinde konumsal doğruluk kriterlerinin de değerlendirmesi mümkün olmaktadır. Elde edilen nokta bulutları, SAM ve ortomozaiklerin hata kestirimleri yer kontrol noktaları yardımıyla değerlendirilmelidir. Değerlendirme kriteri olarak Karesel Ortalama Hata $(\mathrm{KOH})$ değerleri yeterlidir.

Çalışmanın gerçekleştiği bölgeler dik yamaçlar barındırdığında İHA görüntülerinin elde edilmesinde kamera çekim açısı ve kullanılacak platform önemli bir yere sahiptir. Dik açılı yüzeylerin belirlenmesinde yüzeylere nadir noktasında nadir açısının belirlenmesi; cephe ve yamaçlar gibi dik yüzeylerin daha iyi izlenmesini sağlamak için yüksek kamera açı değerlerinin olması tercih edilmelidir. İHA platformu ve kamera düzeneğinin türü, izleme yapılacak alanın yapısına göre tercih edilmesi gerekmektedir. Yamaçların yoğun olduğu izleme alanlarında çok motorlu ve yüksek açı değerine sahip platformlar tercih edilirken, düze yakın ve detaysız izleme alanlarında da sabit kanatlı modeller ve düşük kamera açılı düzenekler tercih edilmelidir.

Görüntü örtüşme, model alanlarının oluşturulması için hem boyuna hem de yanal yönler için bindirme oranları yüzdelik olarak ifade edilir ve fotogrametrik işlemlerde önemli bir parametredir. Yüksek bindirme oranları, elde edilecek nokta bulutu yoğunluğunu arttırarak, 3B konum hassasiyetinin artmasına katkı sağlamaktadır. Ayrıca, ortomozaik oluşumundaki bozulmaları azaltmaktadır. Çoklu görüntüler arasında uygun bir eşleşme elde etmek için, en az \%60 veya daha fazla bir boyuna, \%30-40 aralığında da yanal bindirme oranının olmasına dikkat edilmelidir. Önerilen bu alt sınırlar, karmaşık arazilerde (örneğin orman, dik yamaçlar, yoğun engebeli araziler vb.) veya hava koşullarının çok uygun olmadığı rüzgârlı havalarda yapılan uçuşlardan en az etkilenmek (Hafif İHA platformlarındaki beklenmedik manevralar) ve model alanlarında boşluk oluşmaması için arttırılması gereklidir.

Yer örnekleme aralığı (YÖA), bir diğer deyişle yer çözünürlüğü, sensör çözünürlüğüne, lensin türüne ve kalitesine bağlı ve uçuş yüksekliğinin (yani, kameranın yerden olan mesafenin) fonksiyonu olarak tanımlanır. YÖA, iki komşu pikselin merkezleri arasındaki mesafeyi ifade eder. Kamera lens özellikleri, YÖA'yı ve yer yüzeyini etkileyen görüş alanını tanımlayan önemli donanım özelliğidir.

\section{2 İHA Veri Ön İşleme}

İHA görüntüleri analiz edilerek, görüntüler ve yer kontrol noktaları bazı ön işlemlerden geçirilmeli, ortomozaik ve yükseklik modelleri elde edilmelidir. İHA görüntüleri için geleneksel fotogrametrik işlemler yerine Hareketten Oluşum (SfM: Structure from Motion) görüntü işleme algoritmaları kullanılmalıdır. Bu sayede veri işleme performansı artmaktadır. Bilgisayarlı görme algoritmaları ile SfM işlemleri hızlı ve doğru bir şekilde yapılmaktadır. Bu çalışmada SfM işlem adımları Pix4D (https://www.pix4d.com/) ticari yazılımı kullanılarak uygulanmıştır. Bu işlem adımları aşağıdaki gibi verilmektedir.

- Önemli özel noktaların çıkarımı, görüntüler üzerinde özel noktaların çıkarımı, en yaygın SfM seyrek nokta eşlemesi SIFT (Lowe 2004) ve benzeri algoritmalardır. Bu tür dedektörler, girdi görüntüsüne bir filtre uygular ve ardından bu filtrelenen görüntüdeki yerel maksimum ve minimum değerleri bulunarak ekstrem değerler $(\mathrm{x}, \mathrm{y})$ kaydedilir.

- Özel (seyrek) noktaların eşleşmesi, farklı görüntülerdeki benzer ve eş özellikli noktaların eşleşmesi, görüntü çiftleri arasında birbirine en yakın özellikleri eşleştirme prensiplerine dayanır (Snavely 2008). Yapay ve bozuk eşleşmeler mevcut eşleştirmelerde problemlere sebep olsa da belirli geometrik koşulları sağlayan (epipolar geometri) eşleşmeler sayesinde nokta eşleşmeleri kontrol altında tutulabilmektedir. Geometrik koşulların sağlanmasında belirlenmesi gereken model parametreleri için ise RANSAC (Zhang vd. 2019) ve benzeri model uydurma algoritmaları kullanılarak sağlam model parametreleri hesaplanır. Bunun sonucunda eşleşen noktalara bağlı görüntü eşleşme grafikleri de elde edilebilir. Dış parametrelerin kestirimi için de belirli görüntü çiftleri arasında tespit edilen noktalarda seyrek demet dengelemesi uygulanarak kamera noktalarının konumları hesaplanır (Lourakis ve Argyros 2004). 
- Kamera modelinin optimizasyonu, görüntülerin çekildiği kameraya ait Pix4D kütüphanesinde yer alan kamera parametrelerinin verilere göre tekrar optimize edilmesi işlemidir. Görüntü sayısının yüksek olmasına ek olarak farklı bakış açıları, görüntü yoğunluğu, görüntülerde oluşan eğimden kaynaklı perspektif bozulmaların da belirlenmesi ve optimizasyonu gereklidir. Özellikle Gimbal donanımına sahip olmayan İHA sistemlerinde, kamera yeryüzüne göre nadir görüşü kaybedeceğinden, yani kameranın bakış ekseninin yüzeye dik olmaması durumunda, platformlarda üç eksendeki dönüklüklerden (yalpalama, dalma, dönme) oluşan perspektif bozulmalar meydana gelir. Veri ön işlemenin detaylı adımları Zeybek ve Şanlığlu (2019)'daki önerilen yöntemlere göre yapılmıştır.

\subsection{Yoğun Eşleme}

Görüntü eşleştirme işlemi, fotogrametrik oluşturma prensibine dayanmaktadır. Bu koşulda, her görüntüde yer alan nokta en az iki ve hatta üç resimde görünür olması gerekir. Görüntülerdeki nokta ve ilgili projeksiyon merkezi bir görüntüleme 1şını tanımlar. İç yöneltme (asal mesafe, asal nokta, mercek bozulması) ve dış yöneltme (görüntünün konumu ve dönüşümü) parametrelerinin bilinmesiyle, görüntü noktasının koordinatları görüntü ışınlarının uzayda kesişimiyle nokta 3B yeniden oluşturulabilir (Sanlioglu vd. 2013; Ressl vd. 2016).

Bilinen kamera modelleri ve dönüklükleriyle çoklu stereo algoritma, yüzeye ait yoğun nokta bulutunun üretilmesini sağlamaktadır. Tipik olarak, bu teknik, görüntüler arasındaki en iyi eşleşmeleri belirlemek için bir piksel grid üzerinde sistematik bir arama uygular ve sonuç olarak SfM'nin veri ön işleme adımının özellik eşleştirmesinden daha yüksek hassasiyete sahip olan yoğun $3 \mathrm{~B}$ nokta bulutunun üretilmesini sağlar. Bu sayede topoğrafik yüzeye ait detaylı nokta bulutları elde edilir. Tam resimler aynı anda işlendiğinden, çoklu görüntü stereo özellikle yoğun bir hesaplama yüküne erişmektedir. Ancak, çoğu görüntü tabanlı 3B modelleme programları ve algoritmaları, görüntüleri referans gruplara ve yakınlıklarına göre alt gruplara ayırarak veya çözünürlüğün boyutunu ayarlanmasıyla performans artırma seçeneğine sahiptir (Furukawa ve Ponce 2010; Küng vd. 2011).

SfM, nesnelerin ve yüzeylerin 3B geometrisini oluşturmak için çoklu kamera bakış perspektifinden elde edilen görüntüleri kullanır (Fonstad vd. 2013). Yoğun bir şekilde fotogrametri prensiplerine dayanan, örtüşen bakış açılarından çekilmiş çok sayıda fotoğrafın gözlemlenen ortamı 3B oluşturmak için birleştirildiği bir bilgisayarlı görme tekniğidir. Geleneksel hava fotogrametrisinde tipik olarak paralel uçuş bloklarının düzenli olarak üst üste binen görüntü şeritlerine ihtiyaç duyulurken, SfM, herhangi bir objeye ait, bina, köprü, topoğrafik yüzey vb. nesnelere ait rastgele çekilmiş görüntülerden objenin üç boyutlu geometrisini oluşturmak için tasarlanmıştır (Snavely 2008). Özet olarak SfM mevcut birçok tekniği SIFT (Lowe 2004), RANSAC (Fischler ve Bolles 1981), seyrek demet dengelemesi (Lourakis ve Argyros 2004) algoritmalarını sağlam bir sistemde birleştiren bir yapıdır (Snavely 2008).Bu sistem sayesinde farklı koleksiyon ve rastgele dizilime ve çekim anına sahip görüntüler birleştirilerek 3B geometrik nokta bulutlarına dönüştürülür. Bilinen kamera parametre ve konumlarıyla, çoklu görüşlü stereo algoritması sayesinde, yüzeye ait yoğun bir nokta bulutu üretilebilmektedir. Genel olarak, bu teknik, görüntü çiftleri arasında en iyi eşleșmeyi tanımlamak için piksel gridleri üzerinde sistematik bir arama uygulayacağından, sonuçlar, ilk SfM özellik eşleme işlemine göre daha fazla hassasiyette ve önemli ölçüde yüksek yoğunluğa sahip 3B nokta üretimini sağlar.

\subsection{SYM ve Ortomozaik Üretimi}

3B modeller ve ortofotolar, yüzeylere ait yüksek çözünürlüklü haritalama için kullanışlı veri altlıklarıdır. Üçgenleme veya grid enterpolasyonları kullanılarak, yoğun, memleket koordinatlarına dönüştürülmüş nokta bulutundan SYM ve ortodüzeltilmiş ortomozaikler veri analiz teknikleri ile üretilmektedir.

3B modelin herhangi bir kısmının veya tamamının gerçek ortofotoları, üretilen 3B model ve görüntülerin geometrilerine bağlı olarak, İHA görüntülerinden ortofoto-mozaiği üretilir. Ayrıca, kullanılan yazılıma bağlı olarak (pek çok yazılımda kullanılmaktadır), 3B model görselleştirme ve etkileşim için ortak 3B görselleştirme formatlarında (ör. Obj, .ply, .pdf, vb.) görüntü giydirilmiş model olarak da elde edilebilir ve kaydedilebilir.

Bu çalışmada Pix4D Mapper yazılımı ile elde edilen nokta bulutları üzerinden deterministik ve grid üretimi hızlı bir metot olan Ters Ağırlık Mesafe (IDW) enterpolasyon yöntemi kullanılarak SYM üretilmesi uygun görülmüştür.

\subsection{Görüntü Eşleme}

Görüntü çakıştırma (veya görüntü eşleme), farklı görüntüler arasındaki ilişkilerin tanımlanmasında her bir görüntüde yapılan ölçümlerin tek bir referans görüntü koordinat sisteminde tanımlanmasını sağlar. Görüntüler arasındaki ilişkininin tanımlanması için farklı görüntülere ait dönüşüm parametrelerine ihtiyaç duyulur. Görüntü dönüşüm parametreleri, farklı görüntüler arasındaki kamera veya sensör (konum veya işaret yönü gibi) değişikliklerini hesaba katarak, statik topoğrafya alanlarındaki görüntü özelliklerinin karşılaştırılmasını ve tanımlanmasını yaparak belirlenir. İHA ile elde edilmiş distorsiyon hataları giderilmiş ve koordinatlandırılmış ortomozaik görüntüler ile sabit ve referans ortomozaikler sabit olarak kabul edilebilir. Bu durumda aynı koordinat sistemine sahip farklı zamanlarda elde edilen ortomozaikler arasındaki benzerlik ve farklılıklardan yararlanarak görüntüler üzerindeki topoğrafik yüzey özellikleri incelenebilmektedir. 
Görüntü eşleme işlemlerinin temelinde benzerlik alanları arasındaki ilişkinin çok verimli bir şekilde hesaplanması klasik bir mesafe ölçütü, karesel farkın toplamıyla (SSD) tespit edilir. Bölgesel eşleştirme temelli en yaygın kullanılan benzerlik ölçümlerinden biri de normalleştirilmiş çapraz korelasyon (NCC) yöntemidir. Diğer yöntemler arasında ise, görüntülerden elde edilen lokal özellikler ve kenar çıkarımlarıdır. Bu özellikler, yüksek konumsal doğruluklu ortomozaiklerden çıkartılarak yüzey hareketlerinin tespitinde kullanılabilmektedir.

Jeodezik koordinat sistemlerine dönüştürülen görüntüler, aynı datum ve koordinat sisteminde tanımlanmalıdır. Özellik ve kenar çıkarımlarında üretilen özellikler farklı hataları barındırır. Mozaiklerin bulanık olması, gerçek orto görüntüleri içermemesi, gölgeli alanların olması vb. hatalardır. Bu hatalar eşleme kısmında sağlamlığı bozmakta ve sonuçların yanlış yorumlanmasına sebep olmaktadır. Bu nedenle özellik eşleme yöntemi öncesi bu hataların minimize edilmesi gerekir veya özelliklerin tespit edilmesinde daha sağlam sonuçlar üreten algoritmalar kullanılmalıdır. Burada referans pencere yöntemiyle belirli arama pikseli limitlerine bakılarak sonuçların değerlendirilmesi yoluna gidilmiştir. Bunun için hassas eşleme ve yaklaşık eşleme olarak iki farklı yaklaşım bulunmaktadır. Heyelan hareketlerinin yüksek duyarlıkta belirlenmesi için eşleştirmelerin de yüksek duyarlıkta olması gereklidir. Görüntüyü oluşturan matrislerin yüksek boyutlu olması sebebiyle görüntü boyutlarının ayrıca değerlendirilmeye alınırken optimum süre hesaba katılarak işlemler sürdürülmelidir. Aksi halde işlem süreleri büyük oranda uzayacaktır. Eşlemede ayrıca eşleme oranlarına da bakılarak eşleşmede ki yüzdelik için limitler uygulanmaktadır. Ayrıca görüntüler frekanslara dönüştürülerek aralarındaki özellikler de korelasyon maksimum değerlerine göre tespit edilebilmektedir.

\subsubsection{IMCORR AlgoritmasI}

IMCORR iki görüntü ve bir dizi giriş parametresi ile görüntüler arasında küçük alt görüntü pencerelerini eşleştirmeye çalışan bir yöntemdir. IMCORR, görüntüleri ve boyutlarını, yonga olarak adlandırılan arama çerçeve boyutunu belirleyen parametrelerin, referans yonga boyutu, grid aralığını ve çıktı dosyasının belirlenmesiyle çalışmaktadır. Ayrıca, arama yonga merkezlerinin önceden ayarlanmış aralık değerleri, tahmini hareketlerin üst limitlerine göre belirlenmelidir. Bununla birlikte IMCORR'un yer değiştirmeleri bulmaya çalıştığı alan sınırlaması yapılmadan tüm görüntüdeki alanların analiz edilmesi sağlanır. Eğer yer değiştirmelerin yerleri tam olarak bilinirse bu kesme işleminin yapılması analiz performansını artırabilmektedir.

IMCORR her bir referans grid noktasında, referans yongasının arama yongasına tamamen yerleşen her aralık için bir korelasyon endeksi hesaplar ve çevresindeki en iyi tam-piksel eşleşmesi korelasyon değerlerini kaydeder ve maksimum pik nokta korelasyon konumunu piksel altı hassasiyete enterpole ederek tespit eder (Scambos vd. 1992). Korelasyon endeksi aşağıdaki denkleme göre hesaplanır:

$$
K I_{(l, s)}=\frac{\sum_{l, s}\left(r_{(l, s)}-\mu_{r}\right)\left(s_{(l, s)}-\mu_{s}\right)}{\left[\sum_{l, s}\left(r_{(l, s)}-\mu_{r}\right)^{2}\right]^{\frac{1}{2}}\left[\sum_{l, s}\left(s_{(l, s)}-\mu_{s}\right)^{2}\right]^{\frac{1}{2}}}
$$

Burada, korelasyon indeksi $K I_{(l, s)}$, referans ve arama pencereleri, $r_{(l, s)}, s_{(l, s)}$, referans ve arama pencerelerinin ortalama değerleri $\mu_{r}, \mu_{s}$ ile gösterilmiştir. Korelasyon indeksinin değerleri -1 ile 1 arasında değişir. Ayrıca yazılım, referans yongaları için grid merkezlerinin konumlarını, yonga çiftlerini en iyi şekilde eşleştirmek için gereken yer değiştirmeleri (ya da hiçbirinin bulunamadığını gösterir) ve eşleşmelerin geçerliliğini değerlendirmek için kullanılabilecek çeşitli kalite kontrol parametrelerini içeren harici bir dosya da oluşturmaktadır.

\subsubsection{COSI-Corr Algoritması}

İHA ortomozaiklerinin yüksek duyarlılıkta elde edilmesinden sonra, görüntü korelasyonu ve yer değiştirme ölçümlerinin uygulandığı bir diğer yöntem, meydana gelen yatay dinamiklerdeki değişimlerin belirlenmesi için gelişmiş görüntü işleme ve korelasyon yöntemi COSI-Corr'dur. Uygulanan yöntem, COSI-Corr: Optik Olarak Algılanan Görüntülerin ve Korelasyonla Kaydı, optik görüntülerin herhangi bir kaynaktan üretilmiş iki tek bantlı görüntüsü dikkate alınarak çalışmaktadır. Program normalleştirilmiş çapraz kovaryans yönteminin hızlı bir fourier dönüşümü tabanlı versiyonunu kullanmaktadır. Bu tür bir algoritmanın görüntü işlemede en yaygın kullanımı, iki görüntüdeki bağlama nokta çiftlerini eşleştirmek için doğru bir şekilde bulunmasından ibarettir. Bununla birlikte, görüntüler öncesinde koordinatlandırıldığı için, algoritma, görüntülerdeki belirlenen özellikler arasında çok az değişiklik olsa dahi hareketli bölümlerin değişim miktarını bulmaktadır (Leprince vd. 2007).COSI-Corr uygulamasında ayrıca İHA ortomozaiklerinin yanı sıra ortorektifiye olmayan hava fotoğraflarında ve SYM gölgelendirme haritalarına dönüştürülmesiyle de çalışmaktadır. Algoritma tek bantlı görüntüler üzerinde çalışması hasebiyle, çok bantlı RGB görüntüsünün tek bantlı görüntüye dönüştürülmesi gerekir. 
Yazılımda iki korelasyon algoritması kullanılmaktadır. Bunlardan ilki, fourier dönüşümünden elde edilen görüntü çifti arasındaki göreceli yer değiştirmeyi hesaplayan frekans korelasyon yöntemidir. Diğeri ise, görüntüdeki referans görüntü parçasının korelasyon katsayısının mutlak değeri ve diğer görüntüdeki karşılık gelen parçanın mutlak değeri olarak tanımlanan istatistiksel bir korelasyon yöntemidir. Frekans korelatörü fourier tabanlı ve istatistiksel yönteme göre daha doğru sonuçlar üretmektedir. Optik görüntüler arasındaki farkların tespitinde öncelikli olarak kullanılması önerilmektedir (Ayoub vd. 2017). Bununla birlikte, bu korelatör gürültüye karşı daha hassastır ve bu sebeple yüksek kalitedeki optik görüntüler için kullanılmalıdır.

İstatistiksel korelatör, korelasyon katsayısının mutlak değerini maksimuma çıkartarak örneklem sayısı daha az fakat frekans yöntemine göre daha robust bir teknik olarak karşımıza çıkmaktadır. Frekans korelatörü ile tutarsız sonuçlar veren gürültülü optik görüntülerdeki yer değiştirmeler ve SYM gölge haritaları gibi farklı içerikteki görüntülerin ilişkilendirilmesinde kullanılması daha doğru sonuçlar üretmektedir. Elde edilen yer değiştirmelerin tutarlılığını da artırmaktadır. Vektörler, piksel olarak ifade edilen hatalı koordinatlandırma veya yer değiştirme değeri, korelasyon matrisinin maksimumunun her $\mathrm{x}$ ve y eksenleri için ayrı ayrı kuadratik yaklaşımından hesaplanmaktadır.

Korelasyon analizi, farklı pencere boyutları arasında (8-256 piksel), yakın pencereler arasında 4 piksel öteleme ve 2 metrelik (0.07 m YÖA için) bir arama yarıçapı kullanılarak gerçekleştirilebilir. Fakat bu değerlerin tespiti ilgili inceleme alanı için ön bilgi veya deneme gerektiren bir husustur. Bu nedenle farklı parametre kombinasyonları tahmini arama pencereleri veya yer değiştirme boyutlarına uygun olarak seçilmelidir. Korelasyon penceresinin boyutları ise arazide geçen süre farkı arasındaki yüzeydeki karmaşık değişimine bağlı olarak tespit edilmesi gerekmektedir.

COSI-Corr yazılımıyla, korelasyon analizini farklı karşılaştırma pencere boyutlarındaki eksenlere göre ilişkilendirilerek arama aralığındaki eşleşen bölgelerle mesafe tespiti yapılır. Eksenler arasındaki referans bölümdeki maksimum korelasyon değerinin eşleme merkezine olan uzaklıklarının vektörel değerine göre vektör alanları tespit edilebilir.

Yer değiştirme öncesi ve sonrası görüntülerdeki fark alanlarının belirli bir piksel için değişim vektörünün büyüklüğünün (v(xi)) hesaplaması için aşağıdaki formül ele alınmıştır.

$$
\begin{aligned}
& v\left(x_{i}\right)=\sqrt{\sum_{b=1}^{n}\left(c_{\left.b, t 2-c_{b, t 1}\right)^{2}}\right.} \\
& c_{b, t 2}: \text { yer değiştirme sonrası piksel değeri, } \\
& c_{b, t 1}: \text { yer değiştirme öncesi piksel değeri, }
\end{aligned}
$$

$\mathrm{Bu}$ korelasyon değerlerine ait koordinatların her x ve y merkez değerlerine göre yukarıdaki işlem gerçekleştirilerek yer değiştirme vektörü hesaplanır. Vektör değerlerinin bölgede yapılan ölçülerin standart sapması ve ortalama kararsızlık değerlerine göre bir eşik değer belirlenmiştir. Bu durumda eşik değerinden büyük veya ona eşit değerler, o piksel bölgesindeki değişimi deformasyon hareketi olarak belirlenmiştir; diğer değerlerde sistem içindeki hatalar olarak değerlendirilmiştir, çalışmamızdaki eşik değeri şu şekilde formüle edilmiştir:

$$
x_{i}\left\{\begin{array}{cc}
\text { Yer değiştirme anlamlı } & v(x)>\mu+c . \sigma \\
\text { Yer değiştirme anlamsız } & \text { diğer }
\end{array}\right.
$$

Burada $\mu$ ortalama, $\sigma$ standart sapma ve c katsayısı güven aralığını $(1.96=\% 95)$ ifade etmektedir. Bunun dışında maksimum yer değiştirme miktarı da belirlenerek görüntü ve SYM kenarlarında oluşan bozulma etkileri de giderilmiştir. Modellerin doğrulukları standart sapmalara göre değerlendirilerek demet dengelemesi sonuçlarından alınmıştır. Ortalama değer, demet dengelemesine göre bakıldığında herhangi bir kayıklık olmadığını kanıtlamaktadır. $\sigma$ değeri eşitlik (4)'e göre İHA1 ve İHA2 model KOH değerlerinden türetilmiştir.

$$
\sigma=\sqrt{\sigma_{T, 1}^{2}+\sigma_{T, 2}^{2}}
$$

\subsection{Iki Periyot Zaman Aralığındaki Heyelan Hızının Hesaplanması}

Özellik izleme yöntemleri, resim çiftindeki (ilk ve son görüntü) özellikleri piksel koordinatlarını vermektedir. 3B jeodezik koordinatlarla birlikte görüntülerden üretilen ortomozaik görüntülerin karşılaştırılmasıyla konumsal farklar elde edilmektedir. Hızlar ise, jeodezik konumdaki değişikliklerden sonra, yer değiştirme miktarını görüntüler arasında geçen zaman farklarına bölünerek hesaplanır. 


\section{Uygulama}

Uygulamada iki farklı zamanda elde edilen İHA görüntüleri kullanılmıştır. Uçuş platformu olarak çok motorlu (6 motorlu) TM-GEO1 İHA modeli tercih edilmiştir. İHA üzerinde Canon PowerShot SX260HS 4.54000x3000 marka ve model kamera kullanılmıştır. Görüntüler geniş kapsamlı olacak şekilde ilk periyotta 570 adet, ikinci periyotta ise 828 adet görüntü elde edilmiştir. Uçuş yüksekliği her iki periyot için ortalama 150 m'dir. Üretilen ortomozaiklerden bu çalışma alanı için ilgili alan tespit edilerek kırpılmıştır. İHA verileri Pix4D Mapper yazılımıyla değerlendirilmiştir. Veri analizleri, Windows 64 bit işletim sistemli i5 $3.00 \mathrm{GHz}$ işlemcili 8GB Ram kapasiteli bir bilgisayarda $\mathrm{R}$ programlama dilinde yapılmıştır (R Core Team 2016). Bilgisayar özelliklerinin artırılması veri işleme süresinin kısalmasında önemli bir parametre olarak görülmektedir. Değerlendirme fotogrametrik esaslara dayalı hareketten oluşum (SfM) yöntemi süreçlerine göre yapılmıştır. SfM uygulaması sonucunda ortomozaikler, nokta bulutları ve SYM verileri yer kontrol nokta koordinatları yardımıyla ülke koordinat sistemlerine bağlı olarak aynı koordinat sisteminde üretilmiştir. Heyelan bölgesinde çıplak arazi kısımdaki hareketlerin incelenmesi amaçlandığından Pix4D yazılımından üretilen SYM, Sayısal Arazi Modeli (SAM) olarak kabul edilmiştir. Filtreleme uygulaması yapılmamasındaki sebep ise orman alanlarının filtrelenmesinde başarıya ulaşılırken yoğun ve karmaşık topoğrafyada filtreleme hatası artarak veri kayıplarına sebep olmuştur. Bu nedenle SYM modelleri SAM olarak kabul edilip analizler yapılmıştır. İncelenen alanın genelinde hâlihazırda bitki örtüsü yer almamaktadır. Yalnızca kuzey bölümlerde bitki örtüsü ve bozulmuş yapıda orman yer almaktadir.

Üretilen SYM ve ortomozaikler 1. ve 2. periyot veri analiz sonuçlarında sırasıyla, $5.15 \mathrm{~cm}$ ve $5.38 \mathrm{~cm}$ çözünürlükte üretilmiştir. Ayrıca 3 farklı (RGB) bantlarında üretilmiştir. Fakat her bant için analiz yapılması yerine tek bant üzerinden analizin yapılması daha pratik bulunmuştur. Bununla birlikte belirli bantlar her bölgede oluşmadığında bu yöntem daha sağlamdır. RGB bileşenlerinin ağırlıklı toplamını oluşturarak RGB değerlerini gri tonlama tek bant değerlerine dönüştürmek için:

$$
0.2989 * R+0.5870 * G+0.1140 * B
$$

formülünden yararlanılmıştır. Uygulamayı kapsayan iki farklı periyot verisi için eşitlik (5)'ten yararlanarak ortomozaikler tek banda indirgenmiştir (Şekil 2). 

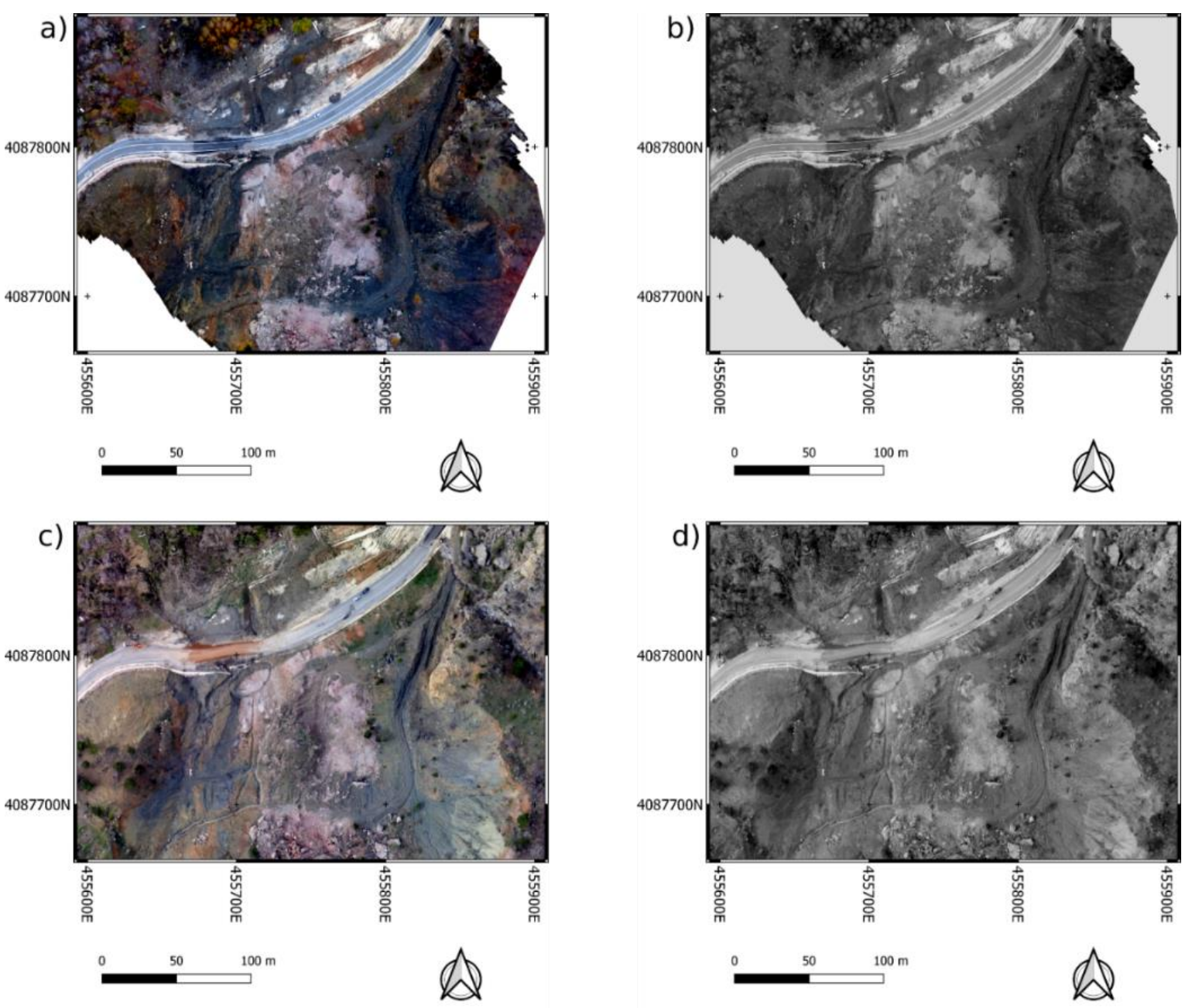

Şekil 2: RGB ortomozaik görüntüler ve tek banda dönüştürülmüş hali, a) IHA 1. Periyot RGB ortomozaik görüntü, b) IHA1. Periyot tek bantı ortomozaik, c) IHA 2. Periyot RGB ortomozaik görüntü, d) IHA 2. Periyot tek bantı ortomozaik.

Tablo 1: IHA verilerinin elde ediliş tarihleri ve aralarındaki gün farkı

\begin{tabular}{|l|l|l|}
\hline Veri & Veri Tarihi & Zaman Fark1 (Gün) \\
\hline İHA Period 1 & 16.11 .2014 & - \\
\hline İHA Period 2 & 26.04 .2015 & 161 \\
\hline
\end{tabular}


a)

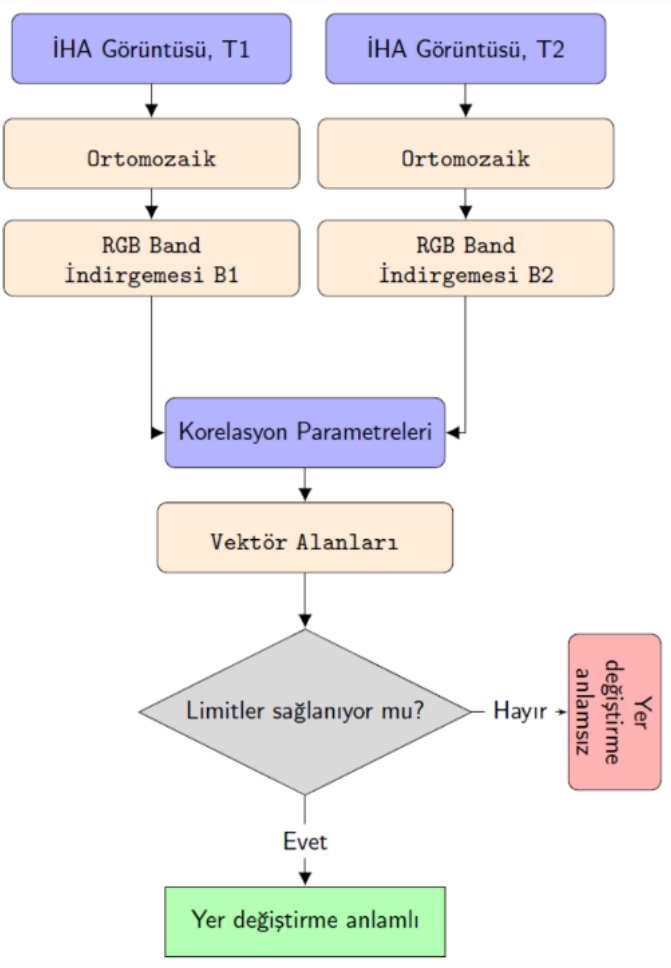

b)

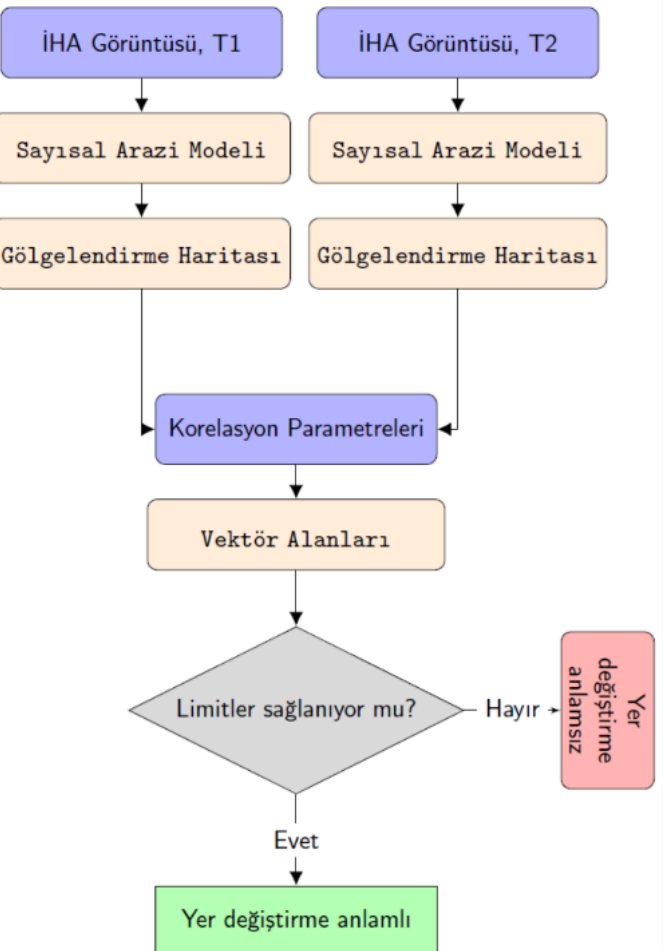

Şekil 3: Ortomozaik ve SAM gölgeli haritaların değerlendirilmesinde işlem akışı a) ortomozaik görüntüler, b) SAM gölgelendirme haritası

İHA görüntü tarihleri ve aradan geçen gün sayısı Tablo 1'de verilmiştir. Görsel incelemeyle aradan geçen süre zarfında bölgede hareketler açık olarak görülmektedir. Uygulamadaki iş akışı Şekil 3 'te verilmiştir. Bu iş akışı her iki yüzey tespit çalışmasında da uygulanmıştır.

\subsection{Sayısal Arazi Modellerinin Karşılaştırılması}

İHA görüntülerinden üretilen SAM'ler arasındaki yükseklik farklarının haritası,

$$
\Delta z=S A M_{U A V 2}-S A M_{U A V 1}
$$

eşitliğine göre SAM çözünürlüğünde elde edilmiştir. Farklı zamanlarda üretilen grid modellerinin çözünürlüğü yükseklik ve kamera parametrelerine bağlı olarak değişmesinden dolayı $(0.0515$ ve $0.0538 \mathrm{~cm})$, yer örnekleme aralığ $\mathrm{iki}$ periyot SAM gridleri için eşitleme işlemine tabi tutulmuş $0.07 \mathrm{~m}$ yer örnekleme aralığına getirilmiştir.

Burada, $\Delta$ z İHA SAM verileri arasındaki yükseklik bileşenindeki kabarma/çökme farkıdır. SAM modelleri arasındaki yükseklik farkları bölgedeki GNSS noktaları arasındaki farklara göre de değerlendirilmiş ve minimum/maksimum değerleri $-5 \mathrm{~m}$ ile $+5 \mathrm{~m}$ aralığında tutulmuştur. Bu limit değerleri SAM modellerinin kenarlarında oluşan bozuklukları da karşılaştırma dışında bıraktığı için istatistiksel ortaya çıkan uyuşumsuz ölçüleri bir nebze azaltmaya çalışılmıştır. Fakat yer değiştirmelerin daha anlamlı olması için bu değer yine $\pm 3 \mathrm{~m}$ civarındaki değerler için analizlerde kullanılmıştır. Gürültülerden ayıklama işlemi basit şekilde olurken gerçek deformasyon değerlerinin elemine edilmemesine de dikkat edildiği için bu iki aşama uygulanmıştır. Tüm ham raster verilerin karşılaştırmaya tabi tutulması ve sonrasında tanımlayıcı istatistik değerlerinin yorumlanması, deformasyonları büyülterek yanlış kararların alınmasına sebep olabilir. Bu nedenle uygulamada dikkat edilmelidir. Bu limit değerinin yerine SAM gridleri belirli sınırlar aralığında model alanı kırpılarak da işlem sürdürülebilmektedir. Bunun için de yüzeysel değişimin kesin sınırlarının tespit edilmiş olması gerekmektedir.

İnceleme bölgesindeki yüzeyde oluşan hareketlerin oldukça karmaşık yapıda olduğu SAM farklarından da anlaşılmaktadır. Maksimum kabarma ve çökme değerleri SAM içinde sınır ve enterpolasyon hatalarından kaynaklanmaktadır. Yani, bölgenin inceleme alanı dışında kalan filtrelenmeyen alanlarda oluşmaktadır. Heyelanın mekanizmasının anlaşılmasında düşey yönlü hareketler göstermektedir ki, kuzeye yönelim gösteren heyelan materyali eğimin kuzeye doğru azalmasıyla kuzeye hareket eden kütleler kabarma oluştururken, güney kesim ve yamaçlarda ise çökmelerin meydana geldiği görülmektedir. Burada dikkat edilmesi gereken bir diğer husus kuzey topuk bölgesindeki ormanlık alan ve doğu yönündeki sarp bölgelerdeki hatalı değişimlerin varlığıdır. Hâlbuki bu durum enterpolasyon ve morfolojik yüzey hatalarından kaynaklanmaktadır. Bu hataların değerlendirilmemesi doğru yorumlanmasında arazi gözlemlerinin de yapılması gerekliliğini ortaya koymaktadır. 


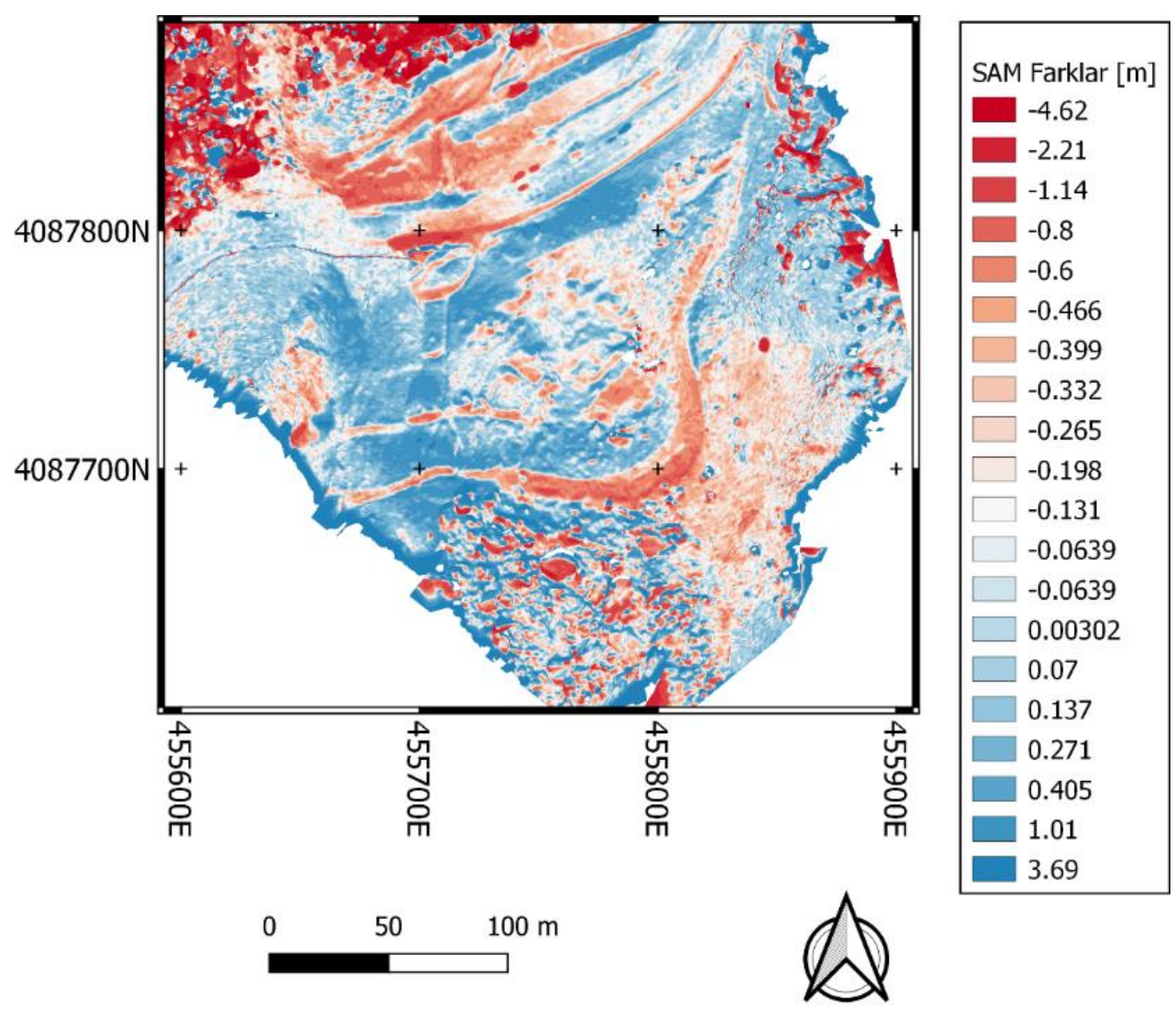

Şekil 4: SAM farklarından elde edilen düşey yönlü hareketler

\section{2 Íki Boyutlu (2B) Yüzey Hareketleri}

Bu uygulama bölümünde, topoğrafik yüzey hareketlerinin oluştuğu heyelan hareketlerinin İHA görüntülerinden elde edilen ortomozaikler yardımıyla tespit edilmeye çalışılmıştır. Bu kapsamda, İHA görüntüleri yardımıyla Konya ilinde seçilen Taşkent ilçesi yakınlarında aktif yer değiştirmeler izlenmiştir.

İHA görüntü sayısının az olması veya konumsal dağılımlarının kötü olması, model bozulmalarına veya eksik bölgelerin oluşmasına yol açabilmektedir. YKN'lerin yoğun kullanılması ve eğik görüntülerin kullanılması, bu tür bozulmaların en aza indirgenmesinde önemli olduğu görülmüştür. Görüntülerin yoğun alınması, karmaşık yüzeylerin çok çeşitli görüş açısı ve yönünden SAM üzerinde yeniden yapılandırılmasına katkı sağladığı da görülmüştür. 33 adet yere gömülü ve İHA görüntülerinde tespit edilebilecek seviyede boyanmış YKN'ler her iki periyotta kalıcı olarak kullanılmıştır. YKN'ler GNSS/RTK yöntemine göre arazi ölçmeleriyle konumları elde edilmiştir. İki arazi ölçüsü sırasında elde edilen GNSS verileri JAVAD-Triump yazılımılla ham verilerin değerlendirilmesiyle konumsal doğrulukları sırasıyla $1.1 \mathrm{~cm}$ yatay doğruluk ve $1.4 \mathrm{~cm}$ düşey doğruluk elde edilmiştir. İHA 1. Periyot ve İHA 2 . Periyot GNSS RTK ölçüleri arasındaki koordinat farklarına ait yer değiştirmeler hesaplanmıştır (Şekil 5).

Modellerin doğruluğu ise, Pix4D Mapper yazılımı demet dengelemesi ve model oluşturma işleminin bir parçası olarak mevcut YKN'ler için yatay ve düşey artık hatalarından KOH'un hesaplanmasıyla değerlendirilmiştir. Maksimum yatay $( \pm 4 \mathrm{~cm})$ ve düşey hatalar $( \pm 9 \mathrm{~cm})$ bağımsız denetleme noktaları olarak kullanılan YKN'ler için elde edilmiştir.

Her iki model için istatistiklerinin toplam $\mathrm{KOH}$ değeri $9 \mathrm{~cm}$ 'den düşük olarak elde edilmiştir. $\sigma$ değeri eşitlik (4)'e göre \pm 0.067 m olarak belirlenmiştir. Bu durumda çalışmanın deformasyon belirleme güven aralığı yani eşitlik (3)'e göre $0.131 \mathrm{~m}$ olarak tespit edilmiştir. Şekillerde analiz ve sonuçlara bağlı kalarak $\pm 3 \mathrm{~m}$ ve üzeri değerler maksimum olarak kabul edilmiştir. Bu değer kenar, ormanlık bölge ve sarp bölgelerde oluşan enterpolasyon hatalarının yorumlanmasında kolaylık sağlamıştır. 


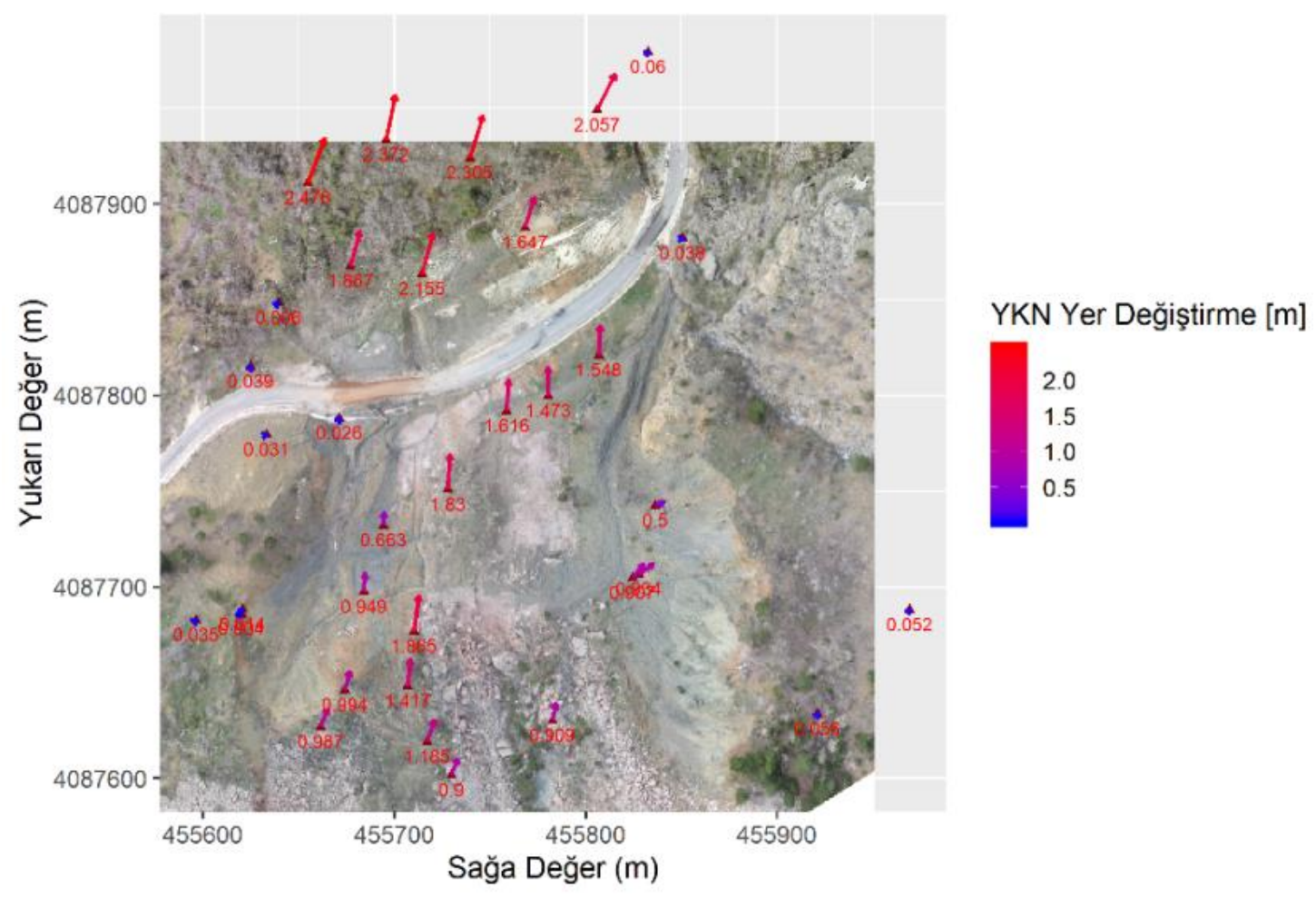

Şekil 5: GNSS/RTK temelli YKN ölçülerine ait yer değiştirme vektörleri

Şekil 5'te, İHA 2. ölçme periyodundan elde edilen ortomozaik üzerine eklenmiş GNSS RTK verilerinin yer değiştirme vektörleri ve büyüklükleri gösterilmektedir. Ortomozaikler üzerine yerleştirilmiş vektörler, hareketin yönü ve boyutu hakkında bilgi vermektedir. Yüzey değişim miktarlarına bakıldığında kayma alanına eşit olarak dağılmadığı görülmektedir ve yer değiştirmeler düzensiz dağılım sergilemiştir. Ayrıca birbirleri arasında büyük ölçüde farklılıklar bulunmaktadır. Heyelan orta bölümlerinde 1.90 m'ye ulaşan yer değiştirmeler bulunurken arazi gözlemlerine göre jeolojik olarak farklı yapıda olan kenar bölgelerin de stabil halde olduğu tespit edilmektedir. Ana ayna ve taç kısmın (güney kesimler) 6 aydan kısa bir sürede yaklaşık $0.90 \mathrm{~m}$ ileriye (kuzey yönünde) doğru hareket etmiştir. Kuzeydeki ormanlığa yakın alanlar ve topuk bölgesi en hareketli kesim, çeşitli yönlerde (kuzey ağıllıklı) $2.50 \mathrm{~m}$ ilerlemesi dikkat çekmektedir.

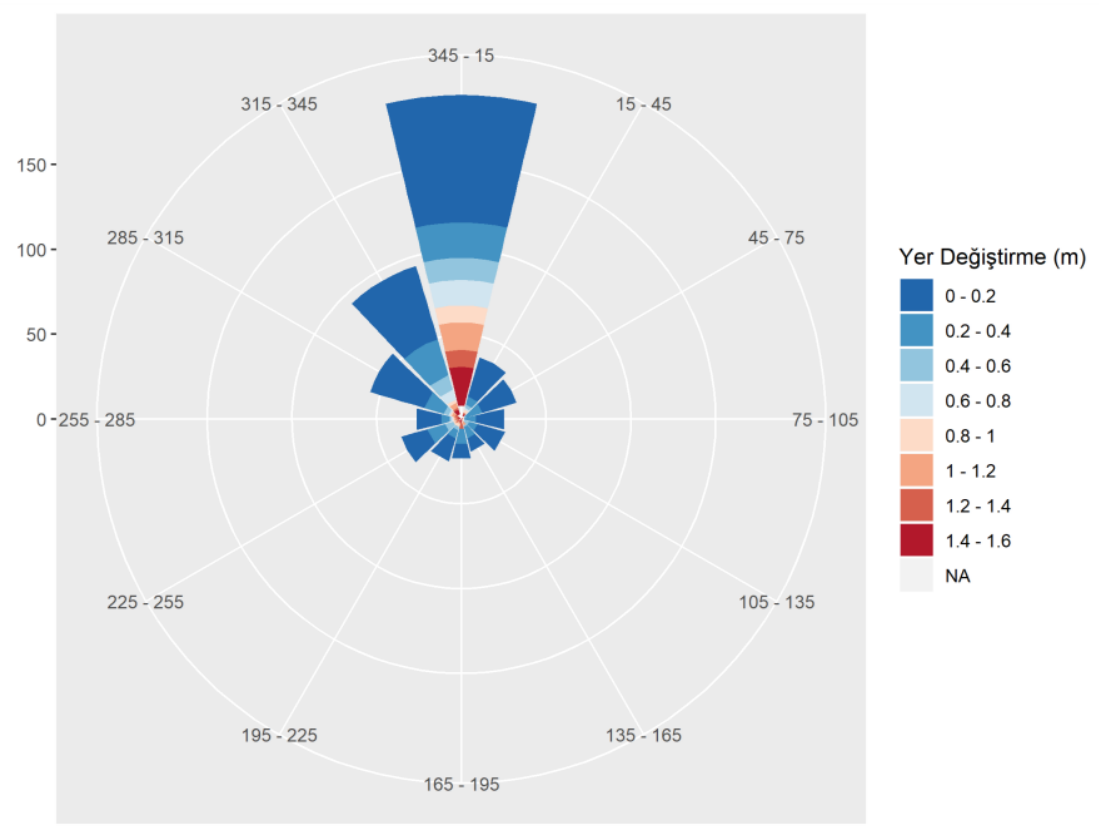

Şekil 6: Yer değiştirmelerin büyüklük ve yönlerine ilişkin dağılımları 
Topoğrafik yüzeyde meydana gelen tüm değişimlerin hangi yöne doğru yoğunlaştıkları vektör alanları ile görsel olarak anlaşılsa da gül diyagramı (rosediagram) ile daha net olarak ortaya koyulmuştur. COSI-Corr sonuçlarından üretilen vektörlerin azimut değerleri Şekil 6'da gösterilmektedir. Vektör yönlerinin yoğunluğunun kuzey yönünde olması dikkat çekmektedir. Büyük (1 m ve üzeri) ve orta büyüklükteki $(0.4-0.8 \mathrm{~m})$ kütle hareketleri kuzey yöne doğru varlığı tespit edilmiştir.

COSI-Corr ve IMCORR yazılımları kullanılarak heyelan hareketlerinin tespiti gerçekleştirilmiştir. GNSS/RTK verilerine göre tahmini yer değiştirme parametreleri içinde korelasyon eşleme penceresi en az 8 piksel ve üzeri seçilmesi gerektiği belirlenmiştir. İHA ortomozaik verilerinin yüksek çözünürlükteki verileri COSI-Corr yazılımındaki iki farklı algoritma ile analiz edilmiştir. İstatistiksel yöntem veri işleme aşamasında yoğun hesap yükü gerektirdiğinden, geniş korelasyon ve arama çerçevelerinin uygulanmasında uygun olmadığı görülmüş ve sadece belirli piksel aralıklarında değerlendirilmiştir. İstatistiksel analiz uygulamasında 128 piksel değerine kadar analiz yapılabilirken, daha yüksek piksel değerlerine göre analiz oldukça uzun veri işleme süreleri gerektirmektedir. Ortomozaik görüntüler yüksek çözünürlükte olması, topoğrafik pürüzlülüğü fazla olan topoğrafyada gürültülü görüntülerin oluşmasına engel teşkil etmemektedir. Yüksek oranda meydana gelen yer değiştirmeler GNSS'e göre tahmin edildiği için görüntü korelasyon pencere boyutu bu değerlerden daha büyük seçilmiştir. Teorik olarak, pencere boyutu beklenen yer değiştirmenin en az iki katı olması gerekmektedir, fakat sonuçlara göre büyük arama oranları meydana gelen gerçek değişimleri daha iyi tespit etmektedir. COSI-Corr uygulama sonuçlarına bakıldığında istatistiksel değerlerin büyük pencere piksel referans çerçevelerinde daha iyi sonuç verdiği görülmüştür (Tablo 2). Fakat bu yöntem için veri işleme performansının düşük olduğu da not edilmelidir. Veri işleme süresi oldukça uzun sürmektedir. İstatistiksel korelatör ayrıca küçük piksel referans çerçevelerinde gürültülü sonuçlar üretmiştir. En az gürültüye sahip ve uygun sonuçlar 128 ve 256 piksel arama çerçeveleri için geçerlidir. En düşük arama penceresinin 32 piksel seçilmesi de bu çalışma çözünürlüğü $0.07 \mathrm{~m}$ için uygun olduğu görülmüştür. GNSS yer değiştirmelerin de ortaya çıkan sonuçlara uygun ve benzer olduğu Tablo 2 incelendiğinde görülmektedir.
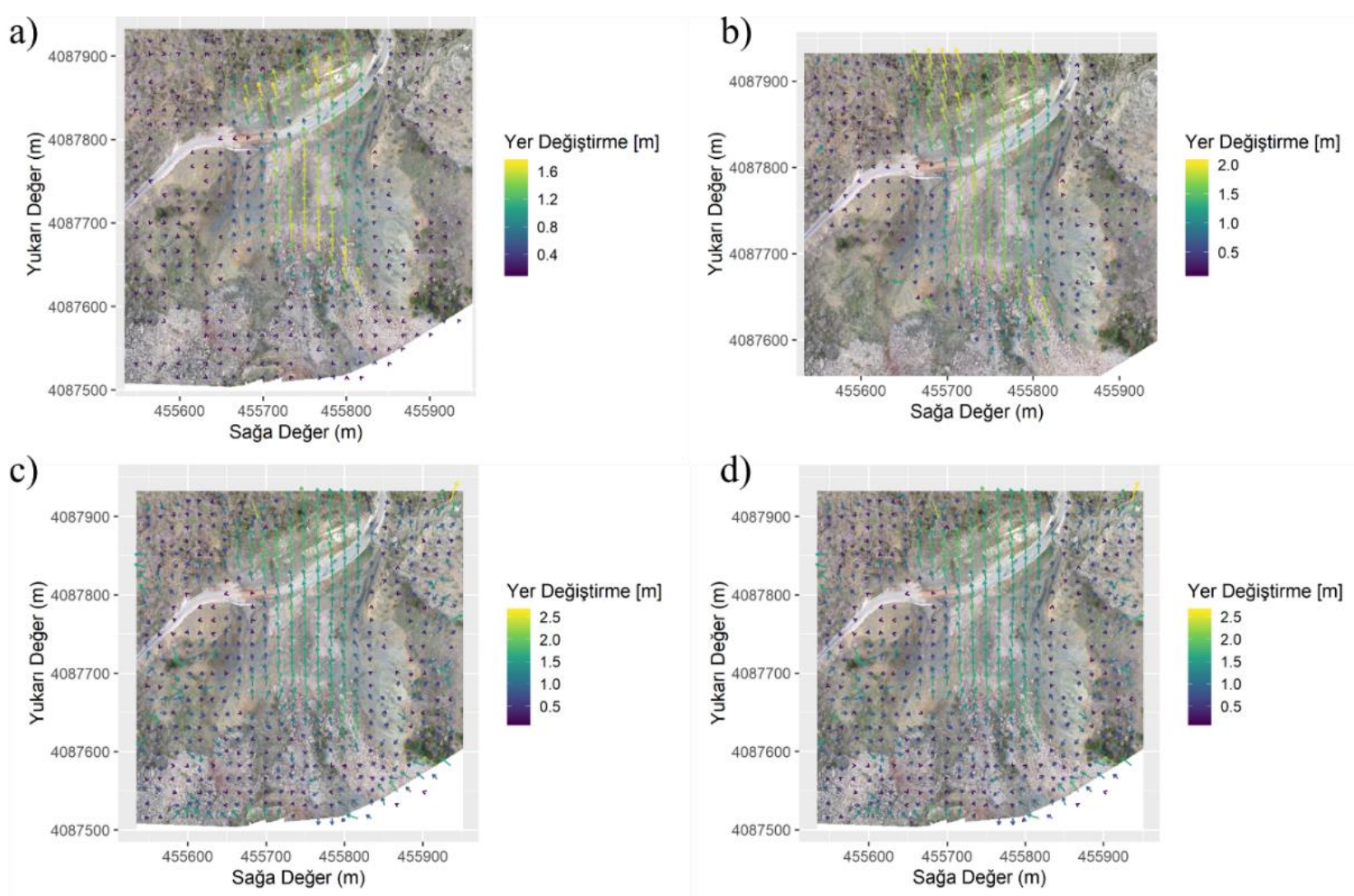

Şekil 7: COSI-Corr algoritması vektör alanları a)128-32 vektör piksel referans ve arama pencereli vektörleri, b) 128-32 piksel referans pencereli istatistiksel vektörleri, c) 256-8 piksel referans ve arama pencereli vektörleri, d) 256-32 piksel referans ve arama pencereli vektörleri. 
Tablo 2: COSI-Corr uygulama sonuçları (Görüntü ID kolonunda istatistiksel korelatör değerlerini vermektedir, diğer değerler pencere piksel genişliklerini vermektedir)

\begin{tabular}{lllll}
\hline Görüntui ID & Min (m) & Maks (m) & $\begin{array}{l}\text { Ortalama } \\
(\mathbf{m})\end{array}$ & Std (m) \\
\hline 128-32-stat_vektor & 0.138 & 2.043 & 0.906 & 0.583 \\
\hline 128-32_vektor & 0.131 & 1.732 & 0.599 & 0.503 \\
\hline 256-32_vektor & 0.145 & 2.615 & 0.909 & 0.507 \\
\hline 256-8_vektor & 0.136 & 2.624 & 0.909 & 0.506 \\
\hline 32-10_stat_vektor & 0.132 & 0.558 & 0.214 & 0.089 \\
\hline 512-32_vektor & 0.134 & 2.987 & 1.368 & 0.676 \\
\hline 64-32_stat_vektor & 0.131 & 2.064 & 0.811 & 0.519 \\
\hline 64-32_vektor & 0.132 & 0.824 & 0.308 & 0.135 \\
\hline
\end{tabular}

İstatistiksel korelatör ağaçlık alanlarda ortomozaik kalitesinin düşük olmasına rağmen yüzeydeki değişimi tam robust olarak tespit edebilmiştir. COSI-Corr uygulamasında girdi verileri olan görüntüler, korelasyon algoritması görüntünün yanlış koordinatlandırma hatalarına karşı hassas olduğundan mümkün mertebede İHA görüntülerinde mutlak yöneltme işleminde yoğun YKN'ler kullanılmıştır. Fakat kullanılacak kamera ve sensörlerin barındırdıkları gürültü ve distorsiyonlar nedeniyle gölgelendirme haritalarındaki gölge ve SAM modelindeki hatalı bölümler, yer değiştirme analizinde olumsuz bir etki oluşturduğu görülmüştür. Bu alanlar genellikle orman alanlarında yer aldığından bu hatalar göz ardı edilmiştir.
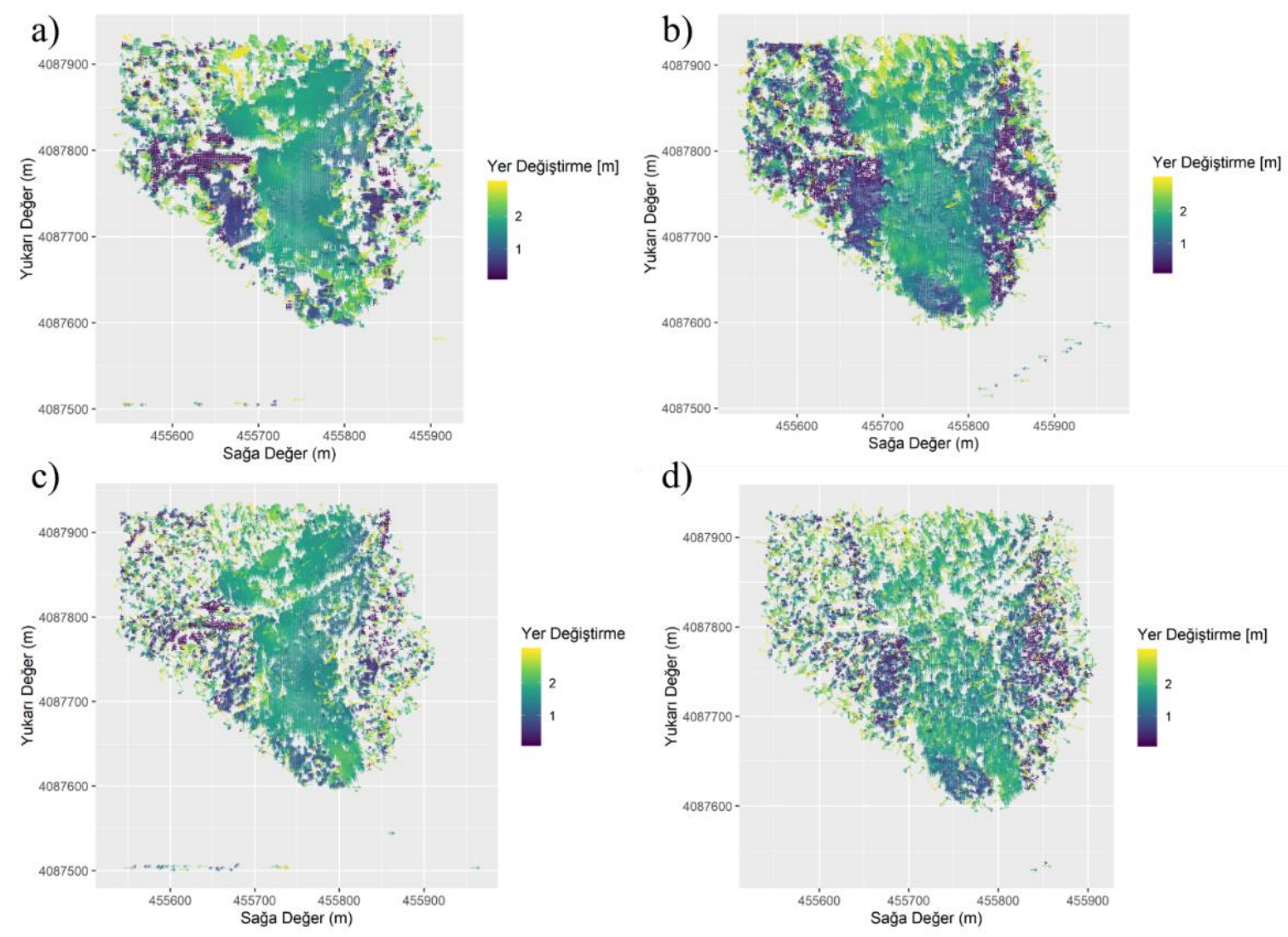

Şekil 8: IMCORR algoritması vektör alanları a)128-256 piksel referans ve arama pencereli ortomozaik, b) 128-256 piksel referans ve arama pencereli SAM gölge haritası, c) 64-256 piksel referans ve arama pencereli ortomozaik, d) 64-256 piksel referans ve arama pencereli SAM gölge haritası.

IMCORR algoritmasıyla iki farklı uygulama yapılmıştır. Yüksek yoğunluktaki nokta bulutlarından elde edilen SAM verileri hem 3B yer değiştirme vektörlerinin bulunmasında hem de SAM modeli üzerinden gölgeleme haritası ile yer değiştirmelerin tespit edilebilirliği açısından COSI-Corr algoritmasına göre avantajlı duruma gelmektedir. Karşılaştırma pencerelerinin merkezleri grid olarak elde edilmiş ve 10 piksel olarak ayarlanmıştır. 
Piksel arama ve referans çerçevelerinin boyutunun düşük olması yer değiştirmelerdeki ortalama hata ve standart sapma değerlerinin de düşük olmasına sebep olmaktadır (Tablo 3). Bu durum yer değiştirmelerin daha az olduğunu gösterse de yüksek arama pencerelerinin ürettiği sonuçlar daha güvenilir olmaktadır, arama penceresi büyüdükçe standart sapmaların artmasının arkasındaki sebeptir. Düşük referans piksel değerlerinde gürültü oranın yüksek olduğu, standart sapmaların da düşük olduğu görülmüştür. Fakat bu durum GNSS sonuçlarıyla görsel olarak karşılaştırıldığında vektör yönleri anlamsız görülmüştür. Bu duruma uyuşumsuz yer değiştirme vektörleri sebep olmaktadır. Geniş piksel alanlı referans pencerelerin ve arama pencere piksellerinin geniş verilmesi daha anlamlı sonuçlar verdiği tespit edilmiştir. Gürültü düzeyinin en düşük olduğu ve vektör alanlarının yüzey değişimini belirgin şekilde ortaya koyduğu sonuçlar Şekil 8'de görülmektedir. Şekil 8 sonuçları Şekil 5'e göre niteliksel olarak karşılaştırıldığında çalışma bölgesinin orta şeridindeki büyük kütle hareketi daha belirgin ve benzer şekilde ortaya çıktığı görülmektedir.

Diğer bir analiz de, SAM'e dayalı gölge haritası ile yapılmıştır. Gölgelendirme (hillshade) operatörü güneş pozisyonu azimut $315^{\circ}$ ve yükseklik açısı $45^{\circ}$ olarak uygulanmıştır. Bu aydınlatma koşulları tipik bir yaz günü öğleden sonraki güneş pozisyonunu temsil etmektedir. Heyelan yönünün ve eğiminin konumu incelendiğinde kuzey yöne doğru azalan eğimde olması sebebiyle bu değerler bölgenin karakteristik noktalarında ve pürüzlü bölgelerinde gölge oluşumunu sağlamaktadır.

Tablo 3: IMCORR uygulama sonuçları (Görüntü ID kolonunda R: referans çerçeve büyüklüğü, S: arama pencere büyüklüğünü ifade etmektedir)

\begin{tabular}{|c|c|c|c|c|}
\hline Görüntü ID & $\operatorname{Min}(\mathbf{m})$ & Maks (m) & Ort. (m) & Std (m) \\
\hline R128S256_İHA_Gri2-1 & 0.131 & 3.000 & 1.517 & 0.671 \\
\hline R128S256_İHA_Gölge_2-1 & 0.131 & 3.000 & 1.436 & 0.687 \\
\hline R16S128_ìHA_Gri2-1 & 0.131 & 3.000 & 1.818 & 0.683 \\
\hline R16S128_İHA_Gölge_2-1 & 0.136 & 3.000 & 1.913 & 0.719 \\
\hline R16S256_İHA_Gri2-1 & 0.131 & 2.991 & 1.715 & 0.626 \\
\hline R16S32_İHA_Gri2-1 & 0.145 & 2.998 & 1.828 & 0.719 \\
\hline R16S32_İHA_Gölge_2-1 & 0.131 & 2.999 & 0.654 & 0.512 \\
\hline R16S64_İHA_Gri2-1 & 0.131 & 2.979 & 0.705 & 0.535 \\
\hline R16S64_İHA_Gölge_2-1 & 0.131 & 2.998 & 1.384 & 0.571 \\
\hline R32S128_ìHA_Gri2-1 & 0.132 & 2.993 & 1.382 & 0.548 \\
\hline R32S128_İHA_Gölge_2-1 & 0.131 & 3.000 & 1.733 & 0.695 \\
\hline R32S256_ïHA_Gri2-1 & 0.131 & 2.999 & 1.793 & 0.725 \\
\hline R32S256_İHA_Gölge_2-1 & 0.133 & 2.999 & 1.613 & 0.625 \\
\hline R32S64_İHA_Gri2-1 & 0.137 & 3.000 & 1.677 & 0.718 \\
\hline R32S64_İHA_Gölge_2-1 & 0.131 & 2.998 & 0.962 & 0.524 \\
\hline R64S128_ìHA_Gri2-1 & 0.131 & 2.999 & 0.984 & 0.498 \\
\hline R64S128_IHA_Gölge_2-1 & 0.131 & 2.998 & 1.571 & 0.652 \\
\hline R64S256_ìHA_Gri2-1 & 0.132 & 3.000 & 1.504 & 0.656 \\
\hline R64S256_İHA_Gölge_2-1 & 0.131 & 2.999 & 1.559 & 0.647 \\
\hline
\end{tabular}

\section{Sonuçlar}

Çalışma alanındaki çıplak arazi yüzeyinde meydana gelen kütle planimetrik olarak uygulanan her iki yönteme göre uyumlu olduğu görülmüş ve ortalama $0.005 \mathrm{~m} /$ gün, 3B olarak $0.011 \mathrm{~m} /$ gün hılarda hareket etmiştir. Yüzey hareketinin yönünde kuzey istikametinde gerçekleşmiştir.

Uygulanan yöntemler, heyelan hareketlerini izleme çalışmalarında karakteristiğinin anlaşılmasında alternatif bir yöntem olarak kullanılabileceğini göstermiştir. Fakat yöntemlerin optik bazlı görüntüler üzerinden analiz yapması, gölgeli ve yoğun bitki örtüsüne sahip alanlardaki ortomozaik ve sayısal arazi modelindeki karmaşık yapılar sebebiyle analiz sonuçlarında yanılmalara sebep olabilmektedir. Bu nedenle sayısal arazi modeli uygulanarak yapılacak analizlerde yüksek çözünürlükte yer noktalarından elde edilmiş modellerin kullanılması harici katkılar sağlamaktadır. Ortomozaik görüntüler üzerinden yapılan analizlerde ise yine ormanlık ve bitki örtüsünün yoğun olduğu alanlarda uygulanan bu yöntemler ortomozaik kalitesindeki düşüklükler sebebiyle doğru sonuçlar üretmemektedir. Bunlara ek olarak hızlı hareket eden kütle hareketlerinde zamana bağlı değişimlerin hızlı oluşumu topoğrafyada derin izler bırakmaktadır. 
Hızlı değişimlerin oluştuğu alanlarda optik temelli izleme çalışmaları yapılması durumunda periyot aralıkları yüzeysel değişimler meydana gelmeden önce hızlı bir şekilde yapılması, yüzey korelasyonlarının tespitine büyük katkılar sağlayacaktır. Karmaşık heyelan, moloz-toprak akması, kaya düşmesi, devrilme gibi meydana gelen kütle hareketlerinde ise görüntüler arasındaki benzeşim oranı azalmaktadır. Bu nedenle uygulanan yöntemlerin uygulanabilirliği de beraberinde azalmaktadır. Bu durum çalışma bölgesindeki gürültülü alanlardan da anlaşılmaktadır. Yalın arazi örtüsüne sahip veya az bitki örtülü alanlarda yatay yayılma hareketi, krip (yavaş hareket), taç çatlaklarının tespiti ve izlenmesi gibi yüzey ve kütle hareketleri bu yöntemlerle yüksek doğruluklarda elde edilebilmektedir.

GNSS verilerinden elde edilen seyrek YKN verileri heyelan bölgesinde oluşan maksimum ve minimum yer değiştirme miktarları ile korelasyon analizlerinden elde edilen yer değiştirmelerin farklı görünmesindeki temel sebep GNSS tekniklerinin noktasal bazda, optik görüntülerin ise alansal bazda çalışmasından süre gelmektedir. Bu sonuca göre bölge hakkında daha genel bir tespit yapılmasında optik ve korelasyon temelli algoritmaların kullanılması daha uygun olmaktadir.

$\mathrm{Bu}$ çalışma, topoğrafik yüzey hareketlerin tespitinde vektör alanlarına bağlı hareketlerin yorumlanmasında İHA verileriyle nasıl belirlenebileceği üzerine yapılmış bir uygulama örneğidir. Bu çalışmadan ortaya çıkan sonuçlara göre, uygulanacak yöntemlerin heyelan hızına bağlı olarak uygulama parametrelerin ve sayısal arazi modelinin kalitesine bağlı sonuçların ortaya çıktığı görülmektedir. Uydu görüntülerinden elde edilen verilere göre çok daha yüksek çözünürlüğe sahip İHA görüntüleriyle lokal hareketlerin tespiti mümkün olmaktadır. Bu durumda orta ve küçük ölçekte meydana gelen topoğrafik hareketlerin istenilen zamanda uydu sistemlerinin koşullarına bağlı kalmadan İHA verileriyle yapılabileceğini kanitlamaktadır.

\section{Tartışma}

Son y1llarda, heyelan analizi için uzaktan algılama teknikleri, çeşitli teknik ve bilimsel gelişmeler ile ilgilenmiştir. Bu teknikler, heyelan risk yönetiminde önemli bir rol oynamaktadır. Çünkü geniş alanların yoğun konumsal örneklemeyle izlenmesine imkân veren bu teknikler, yüksek doğruluklu fakat az sayıda kontrol noktasıyla sınırlı veri sağlayan geleneksel topoğrafik yersel sistemlere (Küresel Konumlandırma Sistemleri ve robotize total station gibi) göre büyük avantajlar sunmaktadır.

Bu makalede heyelanların izlenmesi İHA sistemlerinden elde edilen ortomozaikler yardımıyla yüzey hareketlerinin tespiti, görüntü işleme ve sayısal yükseklik modelleri arasındaki matematiksel işlemlerden faydalanılarak yapılmıştır. Çalışmada görüntüler üzerinden lokal özellik çıkarım yöntemleri kullanarak deformasyon yön ve miktarları tespit edilmiştir. İHA teknolojisi ile yüksek çözünürlüklü verilerin elde edilmesi, bu teknolojinin yüzey değişimlerinde kullanılmasına imkân sağladığı görülmektedir. Farklı algoritmalara dayanarak elde edilen özellik yöntemleri ortomozaiklerle analiz edilerek heyelanların izlenebildiği bu çalışmada yer almıştır. Özellikle görüntü işleme tekniklerinde karmaşık alanlarda heyelan hareketlerinin İHA teknolojisiyle tespiti ve yorumlamasının kolaylaştığ1 görülmüştür. İHA'ların heyelanların izlenmesi çalışmalarında oldukça umut verici bir teknoloji olduğu ve sonuçların optimal uçuş parametreleriyle güvenilir sonuçlar ortaya koyduğu görülmektedir. Mevcut gelişmeler göz önüne alındığında, bu sistemler kullanılarak üretilen sonuç ürünlerin kalitesinin yakın zamanda daha da iyileşmesi tahmin edilmektedir. Bu durumun sonuçları özellikle İHA platformları üreticileri ile birlikte sağladıkları daha iyi donanım ve yazılımlar sayesinde gelecek vaat eden yöntemler olarak ortaya çıkmaktadır. Ancak, veri işleme ve yönetimindeki yoğun işleyişlerinde önemli kısıtlamalar da ortaya çıkmaktadır. Elbette donanımsal ve yazılımsal gelişmeler de bu kısıtlamaları minimize edecektir.

Gelecek dönemlerde, bu çalışmada uygulanan yöntemlerin geliştirilerek obje tabanlı sınıflandırılmış ortomozaikler üzerinden yapılması, grid referans piksel değerleri yerine belirlenen sınıflandırma alanlarındaki hareketlerin tespiti daha anlaşılır ve işlem yükünün bu semantik veriler sayesinde daha hızlı olabileceği düşüncesi doğmuştur. Bununla birlikte topoğrafik ve jeolojik yapıda farklılık gösteren alanların tespiti de bu sayede belirlenmiş olacaktır.

Sonuç olarak İHA teknolojisi ile heyelan bölgelerinin; görüntü işleme, analiz ve haritalama çalışmalarında kullanılabilirliği, tehlike haritalarının hazırlanması, altlık ve envanter oluşturulmasında detaylı bilgiler sunduğu çok açık bir şekilde görülmektedir.

\section{Teşekkür}

COSI-Corr yazılımı için Caltech'e, IMCORR yazılımı için NSDIC'ye ve makalenin ilk halinden bu haline gelmesinde yorumlarıyla büyük katkılar sunan hakemlere teşekkür ediyoruz.

\section{Kaynaklar}

Akgün A., Bulut F., (2007), GIS-based landslide susceptibility for Arsin-Yomra (Trabzon, North Turkey) region, Environ Geol, 51(8), 1377-1387.

Akıncı H., Doğan S., Kılıçoğlu C., Keçeci S.B., (2010), Samsun il merkezinin heyelan duyarlılık haritasının üretilmesi, Harita Teknolojileri Elektronik Dergisi, 2(3), 13-27. 
Aydan O., Ulusay R., Atak V.O., (2008), Evaluation of ground deformations induced by the 1999 Kocaeli earthquake (Turkey) at selected sites on shorelines, Environ Geol, 54(1), 165-182.

Ayoub F., Leprince S., Avouac J.P., (2017), User's Guide to COSI-CORR Co-registration of Optically Sensed Images and Correlation. California Institute of Technology 1200 East California Blvd, Pasadena, CA 91125, USA.

Çan T., Duman T.Y., Olgun Ş., Çörekçioğlu Ş., Gülmez F.K., Elmacı H., Hamzaçebi S., Emre Ö., (2013), Türkiye Heyelan Veri Tabanı, TMMOB Coğrafi Bilgi Sistemleri Kongresi, Ankara.

Çömert R., Avdan U., Şenkal E., (2012), Insansiz Hava Araçlarının Kullanım Alanları Ve Gelecekteki Beklentiler, IV. Uzaktan Algılama ve Coğrafi Bilgi Sistemleri Sempozyumu (UZAL-CBS 2012), 16-19 Ekim, Zonguldak.

Fischler M.A., Bolles R.C., (1981), Random sample consensus: a paradigm for model fitting with applications to image analysis and automated cartography, Commun. ACM, 24(6), 381-395.

Fonstad M.A., Dietrich J.T., Courville B.C., Jensen J.L., Carbonneau P.E., (2013), Topographic structure from motion: a new development in photogrammetric measurement, Earth Surf Proc Land, 38(4), 421-430.

Furukawa Y., Ponce J., (2010), Accurate, dense, and robust multiview stereopsis, IEEE Trans Pattern Anal Mach Intell, 32(8), 13621376.

Gili J.A., Corominas J., Rius J., (2000), Using Global Positioning System techniques in landslide monitoring, Eng Geol, 55(3), 167192.

Gokceoglu M.E.C., (2002), Assessment of landslide susceptibility for a landslide-prone area (north of Yenice, NW Turkey) by fuzzy approach, Environ Geol, 41(6), 720-730.

Handwerger A.L., Roering J.J., Schmidt D.A., (2013), Controls on the seasonal deformation of slow-moving landslides, Earth and Planetary Science Letters, Vol. 377-378, 239-247.

Haque U., Blum P., da Silva P.F., Andersen P., Pilz J., Chalov S.R., Malet J.P., Auflič M.J., Andres N., Poyiadji E., Lamas P.C., Zhang W., Peshevski I., Pétursson H.G., Kurt T., Dobrev N., García-Davalillo J.C., Halkia M., Ferri S., Gaprindashvili G., Engström J., Keellings D., (2016), Fatal landslides in Europe, Landslides, 13(6), 1545-1554.

Hastaoglu K.O., Sanli D.U., (2011), Monitoring Koyulhisar landslide using rapid static GPS: a strategy to remove biases from vertical velocities, Nat Hazards, 58(3), 1275-1294.

Hastaoğlu K.Ö., Poyraz F., Tarık T., Koçbulut F., Şanli U., Yilmaz I., Şanli F.B., Kuçak R.A., Demirel M., Gürsoy Ö., (2014), GPS ve Ps-Insar Yöntemleri Kullanılarak Koyulhisar (Sivas) Heyelanlarının İzlenmesi: İlk Sonuçlar, Gümüşhane Üniversitesi Fen Bilimleri Enstitüsü Dergisi, 4(2), 161-175.

Kaab A., (2002), Monitoring high-mountain terrain deformation from repeated air-and spaceborne optical data: examples using digital aerial imagery and ASTER data, ISPRS J Photogramm, 57(1-2), 39-52.

Kalkan Y., Alkan R.M., Yanalak M., Tari E., Erden T., (2003), Altaş Ambarlı Liman Tesisleri Sahasında Geoteknik ve Jeodezik Yöntemlerle Heyelan İzleme Çalışması, Teknik Rapor, İTÜ Geliştirme Vakfi AR-GE İşletmesi, İstanbul.

Kargel J.S., Leonard G.J., Bishop M.P., Kääb A., Raup B.H., (2014), Global Land Ice Measurements from Space. Springer-Verlag Berlin Heidelberg, 876ss.

Karsli F., Atasoy M., Yalcin A., Reis S., Demir O., Gokceoglu C., (2009), Effects of land-use changes on landslides in a landslideprone area (Ardesen, Rize, NE Turkey), Environ Monit Assess, 156(1-4), 241-255.

Küng O., Strecha C., Beyeler A., Zufferey J.C., Floreano D., Fua P., Gervaix F., (2011), The accuracy of automatic photogrammetric techniques on ultra-light UAV imagery. Int. Arch. Photogramm. Remote Sens. Spatial Inf. Sci., XXXVIII-1/C22, 125-130.

Leprince S., Barbot S., Ayoub F., Avouac J.P., (2007), Automatic and precise orthorectification, coregistration, and subpixel correlation of satellite images, application to ground deformation measurements, IEEE Transactions on Geoscience and Remote Sensing, 45(6), 1529-1558.

Lourakis M.I.A., Argyros A.A., (2004), The design and implementation of a generic sparse bundle adjustment software package based on the levenberg-marquardt algorithm. Technical Report FORTH-ICS / TR-340, Computational Vision and Robotics Laboratory Institute of Computer Science (ICS), Foundation for Research and Tecnology-Hellas (FORTH), Science and Technology Park, Heraklio, Crete, Greece, 23ss.

Lowe D.G., (2004), Distinctive Image Features from Scale-Invariant Keypoints, International Journal of Computer Vision, 60(2), 91110.

Lucieer A., de Jong S.M., Turner D., (2014), Mapping landslide displacements using Structure from Motion (SfM) and image correlation of multi-temporal UAV photography, Prog Phys Geog, 38(1), 97-116.

Maas H.G., Casassa G., Schneider D., Schwalbe E., Wendt A., (2010), Photogrammetric determination of spatio-temporal velocity fields at Glaciar San Rafael in the Northern Patagonian Icefield, The Cryosphere Discussions, 4(4), 2415-2432.

Margottini C., Canuti P., Sassa K., (2013), Landslide Science and Practice Volume 2: Early Warning, Instrumentation and Monitoring. Springer-Verlag Berlin Heidelberg, 685ss.

Messerli A., Grinsted A., (2015), Image georectification and feature tracking toolbox: ImGRAFT, Geoscientific Instrumentation, Methods and Data Systems, 4(1), 23-34.

Niethammer U., James M.R., Rothmund S., Travelletti J., Joswig M., (2012), UAV-based remote sensing of the Super-Sauze landslide: Evaluation and results, Eng Geol, 128, 2-11.

R Core Team, (2016), R: A Language and Environment for Statistical Computing, R Foundation for Statistical Computing, Vienna, Austria, https://www.r-project.org/, [Erişim 21 Haziran 2019].

Ressl C., Brockmann H., Mandlburger G., Pfeifer N., (2016), Dense Image Matching vs. Airborne Laser Scanning - Comparision of two methods for deriving terrain models, Photogrammetrie, Fernerkundung, Geoinformation, 2016(2), 57-73.

Sanlioglu I., Zeybek M., Karauguz G., (2013), Photogrammetric Survey and 3d Modeling of Ivriz Rock Relief in Late Hittite Era, Mediterr Archaeol Ar, 13(2), 147-157.

Sanlioglu I., Zeybek M., Yigit C.O., (2016), Landslide Monitoring with GNSS-PPP on Steep-Slope and Forestry Area: Taşkent Landslide, 2nd International Conference on Engineering and Natural Sciences (ICENS 2016), 24-28 May, Sarajevo, Bosnia and Herzegovina. 
Scaioni M., Longoni L., Melillo V., Papini M., (2014), Remote Sensing for Landslide Investigations: An Overview of Recent Achievements and Perspectives, Remote Sensing, 10.3390/rs60x000x, ss.53.

Scaioni M., (2015), Modern Technologies for Landslide Monitoring and Prediction. Springer-Verlag GmbH Berlin Heidelberg, 249ss.

Scambos T.A., Dutkiewicz M.J., Wilson J.C., Bindschadler R.A., (1992), Application of Image Cross-Correlation to the Measurement of Glacier Velocity Using Satellite Image Data, Remote Sens Environ, 42(3), 177-186.

Singh R., Bartlett D., (2018), Natural Hazards: Earthquakes, Volcanoes, and Landslides. CRC Press, 506ss.

Snavely K.N., (2008), Scene reconstruction and visualization from internet photo collections, PhD Thesis, University of Washington, https://www.cs.cornell.edu/ snavely/publications/thesis/thesis.pdf, [Erişim 21 Haziran 2019].

Turner D., Lucieer A., de Jong S.M., (2015), Time Series Analysis of Landslide Dynamics Using an Unmanned Aerial Vehicle (UAV), Remote Sens, 7(2), 1736-1757.

Türk T., (2018), Determination of mass movements in slow-motion landslides by the Cosi-Corr method, Geomatics, Natural Hazards and Risk, 9(1), 325-336.

van Westen C.J., Castellanos E., Kuriakose S.L., (2008), Spatial data for landslide susceptibility, hazard, and vulnerability assessment: An overview, Eng Geol, 102(3-4), 112-131.

Zeybek M., Şanlığlu İ., (2013), Heyelanların izlenmesinde yersel lazer tarama tekniklerinin kullanılması üzerine araştırmalar, Türkiye Ulusal Fotogrametri ve Uzaktan Algılama Birliği VII. Teknik Sempozyumu (TUFUAB’2013), 23-25 Mayıs, KTÜ, Trabzon.

Zeybek M., Şanlığlu İ., Genç A., (2015), Yüksek Çözünürlüklü Yersel Lazer Tarama Verilerinin Filtrelenmesi ve Filtrelemelerin Heyelan İzlemeye Etkisi, Doğal Afetler ve Çevre Dergisi, 1(1-2), 11-20.

Zeybek M., (2017), Yüksek Çözünürlüklü Topoğrafik Veriler Yardımıyla Heyelanların İzlenmesi, Doktora Tezi, Selçuk Üniversitesi Fen Bilimleri Enstitüsü, Konya, 169ss.

Zeybek M., Şanlığlu İ., (2018), Landslide Monitoring and Assessment for Highway Retainingwall: The Case Study of Taşkent(Turkey) Landslide, ISPRS - International Archives of the Photogrammetry, Remote Sensing and Spatial Information Sciences, XLII-3/W4, 603-608, 10.5194/isprs-archives-xlii-3-w4-603-2018.

Zeybek M., Şanlığlu İ., (2019), Point cloud filtering on UAV based point cloud, Measurement, 133, 99-111.

Zhang Z.L., Li J., Guo Y.L., Lid X., Lin Y.B., Xiao G.B., Wang C., (2019), Robust procedural model fitting with a new geometric similarity estimator, Pattern Recognition, 85, 120-131. 